\title{
Strategy for achieving long-term energy efficiency of European single-family buildings through passive climate adaptation
}

\author{
Luka Pajek, Mitja Košir" \\ University of Ljubljana, Faculty of Civil and Geodetic Engineering, Jamova 2, 1000 Ljubljana, Slovenia
}

\section{H I G H L I G H T S}

- Low energy use of single-family buildings can be assured solely by passive design.

- Passive adaptation only partly counterbalances climate change effects on energy use.

- Total energy use will decrease in cold and temperate and increase in warm climates.

- The most effective long-term climate adaptation measure is applying smaller windows.

- New buildings should be designed according to mid-term optima (2020/2050 period).

\section{A R T I C L E I N F O}

\section{Keywords:}

Building simulation

Parametric analysis

Climate change adaptation

Bioclimatic design

Low energy buildings

\begin{abstract}
A B S T R A C T
The presented study aims to clarify the implications of passive design measures on heating and cooling energy use of single-family residential buildings under European representative climates. In order to address this matter, different values of thermal transmittance (opaque and transparent), window to floor ratio, window distribution, shape factor, diurnal heat storage capacity, external opaque surface solar absorptivity and natural ventilation cooling rates were combined in 496,800 building energy models, which were simulated at eight locations. Because buildings are in use for many decades, the energy use simulations were made considering the projected climate change up to the end of the 21 st century. The results delivered a set of the most effective passive design measures for achieving low energy use in buildings regarding climate type and period. A lower window to floor ratio was identified as the most universally applicable design measure to counterbalance the projected effect of a warming climate. In contrast, other measures vary according to climate type and studied period. Furthermore, it was concluded that it is difficult to neutralise the projected climate change effects on buildings' energy use, even when applying the best performing combination of passive design measures. However, reasonably low energy use can still be assured solely by passive building design, especially in oceanic, warm, and some temperate climate locations. Therefore, the identified trends in energy use and passive design measures represent the foundation for strategies and guidelines aimed at future-proof energy-efficient buildings.
\end{abstract}

\section{Introduction}

The resilience of buildings, especially in the context of climate adaptation, has lately become a significant issue in the field of building energy efficiency. Energy performance of buildings can be improved by increasing the efficiency of passive (e.g. building shape, building

Abbreviations: HVAC, Heating, Ventilation and Air Conditioning; PV, photovoltaic; IPCC, Intergovernmental Panel on Climate Change; WWR, window to wall

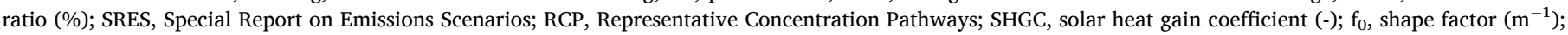

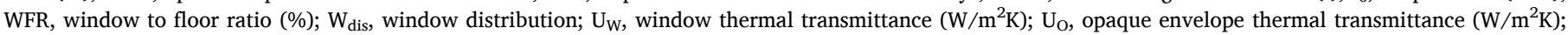

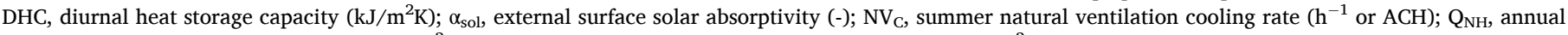

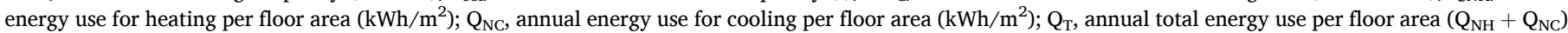

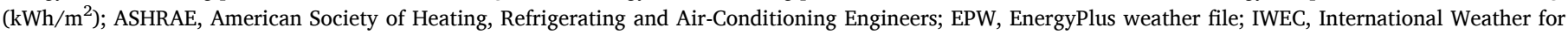
Energy Calculation.

* Corresponding author.

E-mail addresses: luka.pajek@fgg.uni-lj.si (L. Pajek), mitja.kosir@fgg.uni-lj.si (M. Košir). 
envelope design, etc.) or active (e.g. HVAC system, PV systems, etc.) building elements and systems. According to Olgyay [1], Almusaed [2] and Košir [3], the bioclimatic design concept is often used to optimise a building's passive elements in order to adapt it to the relevant climate conditions. Through bioclimatic design and the use of passive building design measures, a higher level of building energy efficiency and indoor thermal comfort can be achieved [4,5]. An attractive feature of some passive building measures, such as building orientation or natural ventilation, is that they generate little or no additional costs for the building project during the design and construction. However, for other passive measures, cost-effectiveness analysis should be executed in order to validate their implementation regarding application costs and energy savings. For this reason, the bioclimatic approach is an essential aspect of cost-optimal energy-efficient solutions.

On the other hand, passive building elements are rigid and difficult to modify after the building has been constructed. For example, changes to the building shape, window distribution or glazing area require substantial interventions in the building or its envelope. Therefore, they are challenging to implement and usually costly. Consequentially, passive building elements represent a substantial lock-in risk for buildings if they are not appropriately designed and evaluated in terms of climate and the intended building use.

In general, passive measures can be divided into four main strategy groups: heat retention, heat admission, heat exclusion and heat dissipation [3]. The selection of appropriate passive design strategies should always depend on climate and location characteristics, as emphasised by Szokolay [6], Košir [3] and Pajek and Košir [7]. At this point, it is essential to understand that with the current trend of global warming, many of the bioclimatic measures that used to be a cost-optimal solution at a specific location might no longer be considered as such. To illustrate, with increasing atmospheric temperatures, at some locations, heat exclusion measures (e.g. smaller glazing area, efficient shading, etc.) can become more important than heat admission measures (e.g. large glazing area for passive solar heating) that were better suited for a colder climate of the past. The worrying projected effects of global warming for the 21 st century could be compensated, at least to some extent, by appropriate and informed climate-adapted building design, considering the trend of projected climate change.

\subsection{Theoretical framework}

In order for bioclimatic building design to be effective, climate adaptation towards future climatic conditions must be considered. Skarbit et al. [8] state that the observations and climate models demonstrate that the climate will become warmer and dryer during the current century. However, the extent of the projected change depends on the climate change scenario used in the models. Several scenarios have been introduced by the Intergovernmental Panel on Climate Change (IPCC) [9], covering various global projected technological, demographic, economic, social and political developments. These scenarios can be grouped into SRES (Special Report on Emissions Scenarios) scenarios introduced in the Third [10] and Fourth [11] IPCC's Assessment Reports and the RCP (Representative Concentration Pathways) scenarios from the Fifth [12] IPCC's Assessment Report. At the moment, it is quite uncertain which scenario will eventually unfold, if any [13]. However, observing the projected outcomes of the SRES and RCP groups of scenarios, it becomes evident that until the end of the 21st century, all the scenarios lead to a warmer future climate.

For this reason, weather file "morphing" methods have been developed to produce design weather data for use in building thermal response simulations that account for future climate change. Several examples of these methods, but not all, were presented by Jentsch et al. [14], Arima et al. [15], Belcher et al. [16], Soga [17] and Jiang et al. [18]. Morphing combines the observed weather data with climate change models [16]. For both RCP (e.g. Spinoni et al. [19]) and SRES (e. g. Berardi and Jafarpur [20]) scenarios, building energy simulations project a decrease in heating demand and increase in cooling demand of buildings. Even under optimistic climate scenarios (e.g. RCP2.6 - projecting a mean global surface temperature increase of $1{ }^{\circ} \mathrm{C}$ by the end of the century), the majority of cities will most likely experience a considerably different climate than today [21] or even extreme conditions that are not currently found in any existing major city, as stated by Bastin et al. [22].

Therefore, using projected future weather data is vital for studying climate change impact on buildings, as highlighted by Jiang et al. [18]. An essential view of the problem was presented by Zhou et al. [23], who highlighted that climate change has a geographically heterogeneous impact on the heating and cooling of buildings. Nevertheless, numerous studies have been conducted evaluating building energy performance against the projected future climate, and a consensus has been reached on the increase in cooling and a decrease in heating demand [24]. An example of such a study was presented by Flores-Larsen et al. [25] in Argentina for residential buildings. They showed a considerable decrease in energy need for heating and an increase in energy need for cooling of buildings. In this context, shading, reducing direct solar gains, and natural ventilation were presented as the most effective design measures to counteract the climate change effects. Furthermore, Andric et al. [26] showed that heating decrease in warm climates was more significant than in cold climates, and Zhai and Helman [27] stated that the total energy use of buildings would increase, predominantly due to the large increase in cooling energy demand. Kishore [28] also drew similar conclusions to the above-stated ones on a case of a typical residential building evaluated under climate change projections for the 21st century under five main climate types of India. It was demonstrated that passive design strategies could reduce the projected annual cooling load by approximately $50-60 \%$ for India's residential buildings.

Concerning the passive and active measures applied to a typical Mediterranean residential building under various climate change scenarios, Pérez-Andreu et al. [29] stated that ventilation has the most negligible impact among several design parameters. In contrast, increased thermal insulation and airtightness will have a more significant effect on future energy performance. Similarly, Rodrigues and Fernandes [30] executed a statistical comparison of random two-storey family building geometries with diverse $U$ values for current and future projected climates in sixteen Mediterranean locations. Importantly, they found that in the future further reduction in $U$ values would continue to be a beneficial design measure for several locations. Future energy needs were also estimated by Ciancio et al. [31] for a hypothetical three-storey residential building placed in 19 European cities. They highlighted that heating energy tends to decrease in northern cities while cooling energy use is expected to increase in southern Europe. Gercek and Arsan [32] stated for the case of Turkey that the most critical parameters concerning the energy performance of residential buildings are related to the transparent surfaces of building envelope. In like manner, Harkouss et al. [33] showed that for the current climate, the optimisation of passive design measures, namely window to wall ratio (WWR), $\mathrm{U}$ value and glazing type, for generic residential building results in using high levels of thermal insulation under cold and temperate climates (e.g. $\mathrm{U}=$ $0.2 \mathrm{~W} / \mathrm{m}^{2} \mathrm{~K}$ ) and lower levels under hot climates (e.g. $\mathrm{U}=0.6 \mathrm{~W} / \mathrm{m}^{2} \mathrm{~K}$ ).

In line with the findings mentioned above, Moazami et al. [34] successfully introduced a robust approach to energy performance evaluation under projected climate change. Similarly, Shen et al. $[35,36]$ proposed an optimisation method for building retrofit planning of a campus building in the US under climate change, for which more than a thousand Pareto fronts were obtained using variables as $U$ value, glazing type, natural ventilation and air infiltration level, heating and cooling system efficiency, renewable energy systems implementation, etc. Although climate change effects were not taken into account, numerous studies in the field of building energy use and operation optimisation, presented by Robic et al. [37], Chiesa et al. [38], Gou et al. [39] and Ciardiello et al. [40], have produced encouraging results. In conclusion, the referenced studies emphasise that it is vital to include a large set of 
variables to optimise a building's energy performance as the identified critical parameters were certainly location-dependent.

\subsection{Knowledge gap identification and study objective}

As noted in the literature review, a building envelope's thermal resistance is known to be one of the most efficient and most resilient passive building approaches to reducing energy use in buildings [41,42]. Therefore, it is also quite common for the policymakers to set U values' upper limit for a building envelope and its components. At the same time, the energy efficiency of buildings can be further enhanced by applying additional passive design measures [43], which do not represent such a substantial financial investment as the implementation of a very thick thermal insulation (example of a study aiming at optimum insulation thickness was shown by Raimundo et al. [44]). Besides, Andrea et al. [45] exposed that homeowners are only aware of bioclimatic principles and that effective planning is needed to improve the residential sector's energy efficiency. As exposed by the abovereferenced studies, the issue is widely researched. However, studies are typically focused on thermal retrofitting of specific commercial or residential buildings (e.g. Shen et al. [36]), aiming at the optimal specific solution (e.g. Shen et al. [35],), are performed with a limited set of variables (e.g. Robic et al. [37], Košir et al. [46]) or do not concern the climate change effects (e.g. Ciardiello et al. [40]). Therefore, a potential long-term contribution of passive design measures to reducing total energy use for heating and cooling of single-family residential buildings under various European climates is unknown. Accordingly, there is a considerable lack of guidelines and recommendations for implementing appropriate passive design measures concerning the building energy efficiency targets. Overall, the following study aims to present crucial information for the design of climate-adapted and energy-efficient buildings that strive for efficient energy use under current and projected climate conditions. A novel holistic approach was devised, applying a comprehensive parametric study in four climatically different intervals. The effectiveness of passive design measures was evaluated based on the resulting building energy performance. Additionally, the identified energy use trends and the corresponding impact of specific design decisions represent a basis for developing future-proof policy strategies and guidelines in the field of energy-efficient buildings.

\section{Methods}

The above-exposed knowledge gap was addressed by performing a comprehensive parametric study. The study was focused on the energy performance of single-family detached residential buildings because this building type represents a substantial share of the European residential building stock [47]. Furthermore, such buildings are also particularly suitable for a parametric study because passive design measures might be highly efficient in optimising their energy use due to high interaction with the climate since its thermal response is envelope dominated [48]. Moreover, residential buildings are typically in use for many decades without being substantially remodelled. Therefore, an integral part of the executed study was searching for the best performing sets of passive design measures concerning the projected climate change until the end of the 21 st century.

Firstly, 496,800 building models were parametrically defined to achieve the paper's purpose, with each case representing a unique combination of passive building design measures defining characteristics of an individual building. As parametric variables, we chose three different building model geometries, ten values of opaque envelope thermal transmittance, ten values of window thermal transmittance with corresponding SHGCs, nine values of the window to floor ratio, two different window distributions, three different diurnal heat storage capacities, four values of external surface solar absorptivity and nine different summer natural ventilation cooling rates. A total number of 496,800 combinations was reached by combining these values in distinctive building models. However, an actual number of combinations would be 583,200 but in some building shapes very large southconcentrated window areas cannot be applied due to limited facade area. Then, each model was simulated under the climate of the eight selected locations in Europe given four distinctive periods: an original "present" climate file and three additional climate files considering climate change projections. Overall, this resulted in a total of $15,897,600$ simulated cases. The annual energy use for heating and cooling was calculated for each model, and best performing models were identified through a 5 th percentile analysis. An overview of the applied research methodology is presented in Fig. 1. A detailed description of the methods used can be found in the following subsections.

\subsection{Energy models and definition of input data}

For the performed analysis, a single-family residential building was selected as a basis for the devised energy models. According to the EU statistical data, the average floor area of a dwelling in the EU 28 is 42.56 $\mathrm{m}^{2}$ per person [49]. In EU member states, a typical number of people per household is between 2 and 3, with an average of 2.3 people in 2019 [50]. Considering the EN 16798-1 standard [51], $43 \mathrm{~m}^{2}$ of floor area per person, three persons per household, and a $25 \%$ addition to floor area due to technical and communication spaces resulted in $162 \mathrm{~m}^{2}$ net floor area per modelled building. Therefore, the geometric characteristics of the model represent an average single-family detached residential building in the EU. The floor-to-floor height was set at $3 \mathrm{~m}$ so that the corresponding volume of the modelled buildings was $486 \mathrm{~m}^{3}$.

Next, all building-related inputs were thoroughly defined to represent a distinctive design and operation of European buildings. Due to practical reasons for limiting the number of total possible combinations in the population and reducing the amount of modelled buildings to a manageable number, several building-related input parameters were set constant for all the models. Most of them are related to building use and operation and are presented in Table 1.

For the parametric study, the following variable input parameters were selected: opaque envelope thermal transmittance $\left(\mathrm{U}_{\mathrm{O}}\right)$, window thermal transmittance $\left(\mathrm{U}_{\mathrm{W}}\right)$ and the corresponding solar heat gain coefficient (SHGC), window to floor ratio (WFR), window distribution $\left(W_{\text {dis }}\right)$, building shape expressed through shape factor $\left(f_{0}\right)$, diurnal heat storage capacity (DHC), external surface solar absorptivity $\left(\alpha_{\text {sol }}\right)$ and summer natural ventilation cooling rate $\left(\mathrm{NV}_{\mathrm{C}}\right)$ (see Table 2). The $\mathrm{U}_{\mathrm{O}}$ parameter was simultaneously altered in each external building envelope element (slab-on-grade, external wall, roof). Unlike in the walls and roof, the DHC of ground floor slab-on-grade construction was not parametrised. There, a concrete slab (i.e. DHC $=146 \mathrm{~kJ} / \mathrm{m}^{2} \mathrm{~K}$ ) was used in all of the cases. The paper aims at achieving universal comparability among the building models. Therefore, WFR was adopted as a variable parameter instead of WWR because the analysed building models with the same WFR also have the same total window area. However, models with the same WWR would not necessarily have the same total window area since also building shape was chosen as a variable parameter of the analysis. Furthermore, the aim of using parameter $\mathrm{W}_{\mathrm{dis}}$ was to evaluate the impact of the focus either on passive solar heating (i.e. south concentrated windows) or ignoring it (i.e. equal area of windows at all orientations) and not the effect of glazing orientation. Information regarding individual parameter ranges, variable increments and the number of the resulting simulated cases is provided in Table 2; see also Fig. 1.

It should be noted that the chosen parameter ranges (Table 2) represent technologically feasible building solutions to the most extensive possible degree. However, the resulting specific cases might sometimes not be practical due to economic and/or buildability reasons. For example, $\mathrm{U}_{\mathrm{O}}$ of $0.10 \mathrm{~W} / \mathrm{m}^{2} \mathrm{~K}$ will result in extremely thick thermal insulation, challenging to execute and questionable from the point of view of return on investment. Moreover, the selected studied passive measures represent the most universally applicable measures. They are 
INPUT DATA AND PARAMETERS

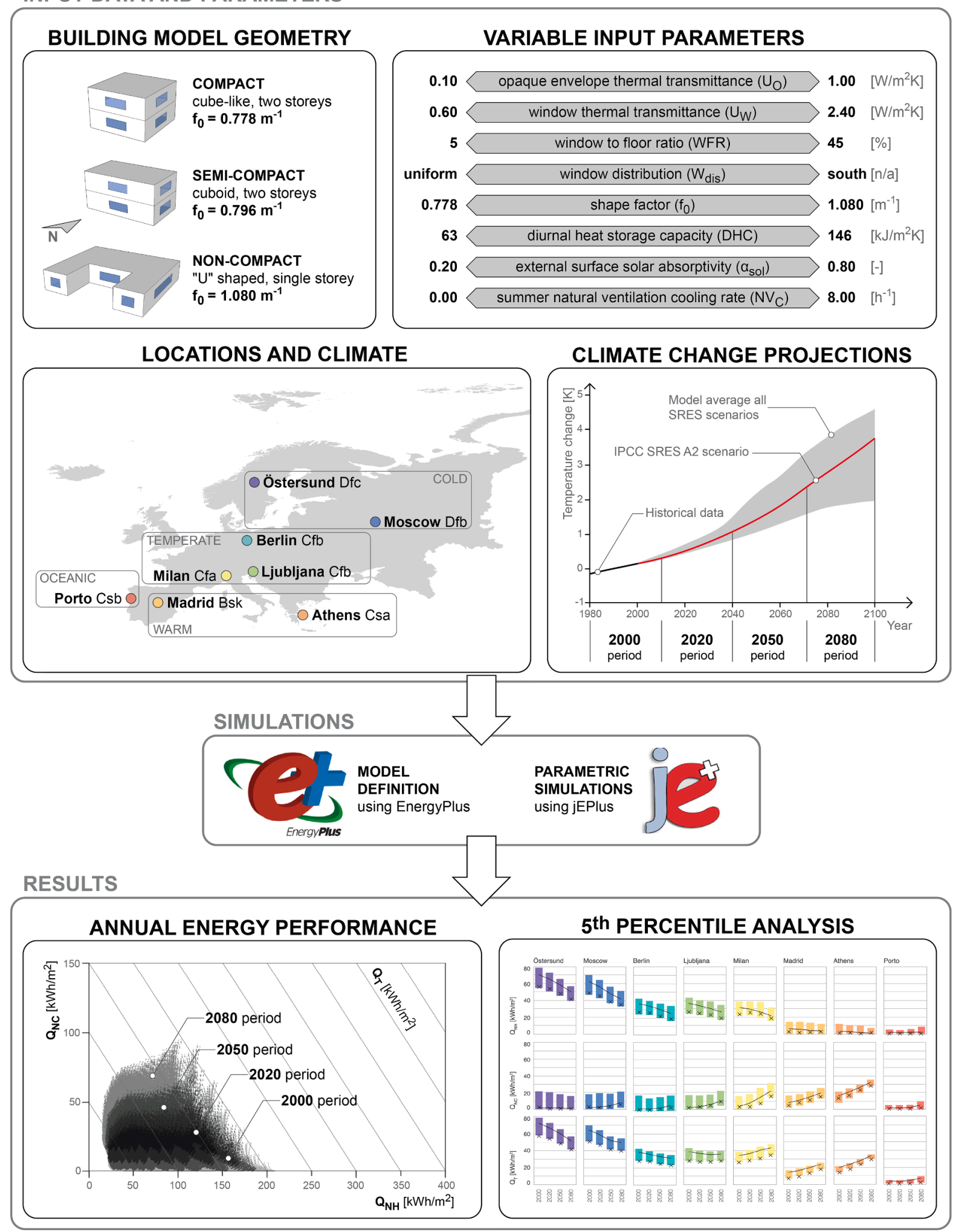

Fig. 1. Overview of the applied research methodology.

used by building designers in contemporary energy-efficient buildings in Europe, either explicitly or implicitly. There are indeed other passive measures (e.g. evaporative cooling) that might be worthy of investigation in the context of building energy performance concerning the projected climate change. However, we opted to limit ourselves to those design measures that are already established in the design community while at the same time showing real potential for enhancing building performance under all studied climates. 
Table 1

Constant input parameters for the energy models.

\begin{tabular}{|c|c|c|}
\hline Parameter & Value & Note \\
\hline Heating set-point & $21{ }^{\circ} \mathrm{C}$ & EN 16798-1, Table B.2 [51] \\
\hline Cooling set-point & $26^{\circ} \mathrm{C}$ & EN 16798-1, Table B.2 [51] \\
\hline Indoor temperature control & operative temperature & Based on Dovjak et al. [52] \\
\hline Infiltration + natural ventilation rate & 0.600 (1st April to 31st October), 0.375 (1st November to 31st March) & $\begin{array}{l}\text { Based on Hou et al. [53], Bekö } \\
\text { et al. [54] }\end{array}$ \\
\hline Internal heat gain rate and schedule (appliances) & $2.4 \mathrm{~W} / \mathrm{m}^{2}$ & EN 16798-1, Annex C [51] \\
\hline Internal heat gain rate and schedule (occupants) & $2.8 \mathrm{~W} / \mathrm{m}^{2}$ & EN 16798-1, Annex C [51] \\
\hline Internal heat gain rate and schedule (lighting) & $3.3 \mathrm{~W} / \mathrm{m}^{2}$ & EN 16798-1, Annex C [51] \\
\hline Shading schedule & active from 1st April till 31st October & $\begin{array}{l}\text { Based on Tzempelikos and } \\
\text { Athienitis [55] }\end{array}$ \\
\hline Shading set-point, type, and operation & $\begin{array}{l}\text { incident solar radiation on window } \geq 130 \mathrm{~W} / \mathrm{m}^{2} \text { and external temperature } \geq 16^{\circ} \mathrm{C} \text {, external } \\
\text { blinds, always block beam solar }\end{array}$ & EN 15232, class A [56] \\
\hline $\begin{array}{l}\text { Building envelope system and external surface } \\
\text { thermal emissivity }\end{array}$ & the externally insulated building envelope, 0.80 & Based on Pisselo [57] \\
\hline
\end{tabular}

Table 2

Variable input parameters for the energy models.

\begin{tabular}{|c|c|c|}
\hline Parameter & $\begin{array}{l}\text { No. of variable } \\
\text { increments }\end{array}$ & Parameter range \\
\hline $\mathrm{U}_{\mathrm{O}}\left[\mathrm{W} / \mathrm{m}^{2} \mathrm{~K}\right]$ & 10 & $0.10,0.15,0.20,0.25,0.30,0.40,0.50,0.60,0.80,1.00$ \\
\hline $\mathrm{U}_{\mathrm{W}}\left[\mathrm{W} / \mathrm{m}^{2} \mathrm{~K}\right]$, in brackets: corresponding SHGC [-] & 10 & $\begin{array}{l}2.40(0.75), 2.20(0.75), 2.00(0.70), 1.80(0.70), 1.60(0.65), 1.40 \\
(0.65), 1.20(0.60), 1.00(0.55), 0.80(0.50), 0.60(0.45)\end{array}$ \\
\hline WFR [\%] & 9 & 5 ("base" case), $10,15,20,25,30,35,40,45$ \\
\hline $\mathrm{W}_{\mathrm{dis}}[\mathrm{n} / \mathrm{a}]$ & 2 & $\begin{array}{l}\text { equal area of windows at all orientations, } \\
\text { south-concentrated windows ( } 3.75 \% \text { of WFR equally distributed among } \\
\text { other orientations) }\end{array}$ \\
\hline $\mathrm{f}_{0}\left[\mathrm{~m}^{-1}\right]$ & 3 & $\begin{array}{l}0.778 \text { (compact, cube-like, two storeys), } \\
0.796 \text { (semi-compact, cuboid, two storeys), } \\
1.080 \text { (non-compact, "U" shaped, single storey) }\end{array}$ \\
\hline $\begin{array}{l}\text { DHC of loadbearing construction }{ }^{\mathrm{a}}\left[\mathrm{kJ} / \mathrm{m}^{2} \mathrm{~K}\right] \text {, in brackets: thickness }[\mathrm{m}] \text {, thermal } \\
\text { conductivity }[\mathrm{W} / \mathrm{mK}] \text {, density }\left[\mathrm{kg} / \mathrm{m}^{3}\right] \text {, specific heat }[\mathrm{J} / \mathrm{kgK}]\end{array}$ & 3 & $\begin{array}{l}63(0.06,0.20,600,2090 \text {, e.g. cross laminated timber }) \\
98(0.15,0.50,1200,920 \text {, e.g. brick), } \\
146(0.24,0.80,2000,960 \text {, e.g. concrete/stone })\end{array}$ \\
\hline$\alpha_{\text {sol }}[-]$ & 4 & $0.2,0.4,0.6,0.8$ \\
\hline $\mathrm{NV}_{\mathrm{C}}^{\mathrm{b}}\left[\mathrm{h}^{-1}\right]$ & 9 & $0,1,2,3,4,5,6,7,8$ \\
\hline total number of models ${ }^{c}$ & 496,800 & \\
\hline
\end{tabular}

${ }^{\mathrm{a}} \mathrm{R}=$ constant $=0.30 \mathrm{~m}^{2} \mathrm{~K} / \mathrm{W}$.

${ }^{\mathrm{b}} \mathrm{NV}_{\mathrm{C}}$ is applied between April and October when the following conditions are met: internal air temperature $>24{ }^{\circ} \mathrm{C}$, external air temperature is between 16 and $30{ }^{\circ} \mathrm{C}$, and temperature difference between internal and external air is $<4 \mathrm{~K}$.

${ }^{c}$ an actual number of combinations would be 583,200 if a compact and non-compact building shape allowed larger WFRs than $35 \%$ or $30 \%$, respectively.

The building shape factor $\left(\mathrm{f}_{0}\right)$ represents the ratio between the building envelope area and the building volume. It was calculated using equation (1).

$f_{0}=\frac{A_{\text {envelope }}}{V_{\text {building }}}$

$\mathrm{A}_{\text {envelope }}$ is the building envelope area (i.e. the area in contact with the external environment), and $\mathrm{V}_{\text {building }}$ is the building volume.

DHC of loadbearing construction was calculated according to equation (2) [58].

$D H C=\sqrt{\frac{P \lambda \rho c}{2 \pi}\left(\frac{\cosh \left(2 t \sqrt{\frac{\pi \rho c}{P \lambda}}\right)-\cos \left(2 t \sqrt{\frac{\pi \rho c}{P \lambda}}\right)}{\cosh \left(2 t \sqrt{\frac{\pi \rho c}{P \lambda}}\right)+\cos \left(2 t \sqrt{\frac{\pi \rho c}{P \lambda}}\right)}\right)}$

$\mathrm{P}$ is the period of $24 \mathrm{~h}$ in seconds, $\lambda$ is material's thermal conductivity in $\mathrm{W} / \mathrm{m} \mathrm{K}, \rho$ is material's density in $\mathrm{kg} / \mathrm{m}^{3}$, $\mathrm{c}$ is material's specific heat in $\mathrm{J} /$ $\mathrm{kg} \mathrm{K}$, and $\mathrm{t}$ is the layer thickness in $\mathrm{m}$.

In terms of building geometry, three distinct shapes (see Fig. 1) with equal volumes and floor areas were modelled following the abovedescribed statistical information about average EU dwellings. The first one is a cube-like, compact building $\left(f_{0}=0.778 \mathrm{~m}^{-1}\right)$ with a square floor plan $(9 \times 9 \mathrm{~m})$, two floors and $6 \mathrm{~m}$ of total height. The second one is a cuboid-shaped building $\left(\mathrm{f}_{0}=0.796 \mathrm{~m}^{-1}\right)$ with a rectangular floor plan
$(12 \times 6.75 \mathrm{~m})$, two floors and $6 \mathrm{~m}$ of total height. The last one is a noncompact building $\left(\mathrm{f}_{0}=1.080 \mathrm{~m}^{-1}\right)$ with a semi-enclosed atrium (i.e. " $\mathrm{U}$ " shaped) and a single storey with $3 \mathrm{~m}$ of total height. Numerical models were implemented in EnergyPlus [59], which is recognised as accurate building energy simulation software with sophisticated features [43]. Each of the models was divided into thermal zones. In particular, each floor was split into four thermal zones according to each cardinal axis. The contact of the slab-on-grade with the ground was simplified by using a constant ground temperature of $18{ }^{\circ} \mathrm{C}$ applied directly below the slabon-grade of the building model.

The defined EnergyPlus models were then entered into the jEPlus [60] software for parametric analysis. Simulations were executed using four time steps per hour and under the presumption that occupant thermal comfort was achieved at all times by the set-point operative temperature for cooling and heating (Table 1). Effectively, this means that the simulated models are in a "free-run" operation when the indoor operative temperature is between 21 and $26^{\circ} \mathrm{C}$. As a result of the energy analysis, the annual energy use for heating $\left(\mathrm{Q}_{\mathrm{NH}}\right)$ and cooling $\left(\mathrm{Q}_{\mathrm{NC}}\right)$ per $\mathrm{m}^{2}$ of floor area was calculated. Several results were evaluated against $\mathrm{Q}_{\mathrm{T}}$, which is the sum of $\mathrm{Q}_{\mathrm{NH}}$ and $\mathrm{Q}_{\mathrm{NC}}$. However, $\mathrm{Q}_{\mathrm{NH}}$ and $\mathrm{Q}_{\mathrm{NC}}$ must be understood only as a part of the overall building energy performance because energy-relevant aspects, such as the efficiency of the heating or cooling system, hot water supply and artificial lighting, are not considered. The specific equations behind the calculations of $\mathrm{Q}_{\mathrm{NH}}$ and $\mathrm{Q}_{\mathrm{NC}}$ in EnergyPlus can be found in Engineering Reference [61]. 
Table 3

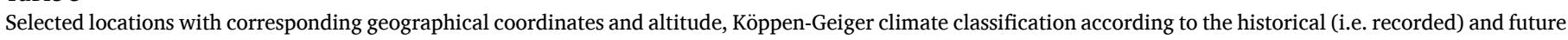
projected climate characteristics and ASHRAE climate zone.

\begin{tabular}{|c|c|c|c|c|c|c|c|}
\hline Location & Country & Latitude & Longitude & Altitude & $\begin{array}{l}\text { Köppen-Geiger (K-G) } \\
\text { climate type }\end{array}$ & $\begin{array}{l}\text { K-G climate (2051-2075, } \\
\text { IPCC SRES A2 scenario) [65] }\end{array}$ & $\begin{array}{l}\text { ASHRAE climate } \\
\text { zone [66] }\end{array}$ \\
\hline Östersund & Sweden & 63.18 & 14.50 & $370 \mathrm{~m}$ & Dfc & $\mathrm{Dfb}$ & 7 \\
\hline Moscow & Russia & 55.75 & 37.63 & $156 \mathrm{~m}$ & $\mathrm{Dfb}$ & $\mathrm{Dfb}$ & $6 \mathrm{~A}$ \\
\hline Berlin & Germany & 52.47 & 13.40 & $49 \mathrm{~m}$ & $\mathrm{Cfb}$ & $\mathrm{Cfb}$ & $5 C$ \\
\hline Ljubljana & Slovenia & 46.22 & 14.48 & $385 \mathrm{~m}$ & $\mathrm{Cfb}$ & $\mathrm{Cfb}$ & $5 \mathrm{~A}$ \\
\hline Milan & Italy & 45.43 & 9.28 & $103 \mathrm{~m}$ & $\mathrm{Cfa}$ & $\mathrm{Cfa}$ & $4 \mathrm{~A}$ \\
\hline Madrid & Spain & 40.45 & -3.55 & $582 \mathrm{~m}$ & Bsk & Bsk & $3 C$ \\
\hline Athens & Greece & 37.90 & 23.73 & $15 \mathrm{~m}$ & Csa & Csa & $3 \mathrm{~A}$ \\
\hline Porto & Portugal & 41.23 & -8.68 & $73 \mathrm{~m}$ & Csb & Csa & $3 C$ \\
\hline
\end{tabular}

\subsection{Selected locations and climate data}

The building energy performance calculations were executed for eight locations across Europe, as presented in Table 3 and Fig. 1. Locations were selected in accordance with our previous findings from bioclimatic potential analyses, presented in Pajek et al. [62] and Košir et al. [63] and thus represent various climate types existing in continental Europe. The necessary weather files (i.e. EPWs) were sourced from the official EnergyPlus web page [64] and represent distinct climate types according to the recorded historical weather data.

The climate data in the obtained EPWs are sourced from the International Weather for Energy Calculation (IWEC) database and represent weather data measured between 1982 and 1999. In the paper, this historical climate data period was labelled as " $2000^{\prime \prime}$. In order to simulate building performance under projected future climate conditions, historical data for the period of 2000 were used to generate projected EPW weather files for the periods "2020" (2011-2040), "2050" (2041-2070) and "2080" (2071-2100). The generation of the projected climate characteristics was executed using the morphing technique in the CCWorldWeatherGen tool [67] introduced by Jentsch et al. [14] from the University of Southampton. As a basis for the executed morphing, the IPCC's SRES A2 projected climate change emission scenario was used. The SRES A2 scenario describes a heterogeneous world with nations focused on self-reliance and local identity, with continuous population growth and increasing GHG emissions (i.e. a regional and economy-focused world), resulting in projected warming above $3{ }^{\circ} \mathrm{C}$ by the end of the current century (Fig. 1) [68]. The SRES A2 climate change scenario has a similar radiative forcing trajectory to a more recent IPCC's RCP8.5 scenario with both reaching about $8 \mathrm{~W} / \mathrm{m}^{2}$ by 2100 , while mean surface temperature change in SRES A2 scenario is projected about $0.3 \mathrm{~K}$ lower than in RCP8.5 [12]. In addition, the projected global mean surface temperature increase for the SRES A2 scenario in 2050 is approximately $1.5{ }^{\circ} \mathrm{C}$, which is midway between the projected temperature change of the RCP8.5 and RCP6.0.

\section{Results}

The following subsections present the simulated building models' energy performance in current and the projected climate scenarios. Section 3.2 provides general guidance on recommended passive measures for long-term energy efficiency. The presented results are evaluated according to the annual energy use for heating $\left(\mathrm{Q}_{\mathrm{NH}}\right)$ and cooling $\left(Q_{N C}\right)$ per $m^{2}$ of building floor area as well as $Q_{T}$, which is the sum of $Q_{N H}$ and $Q_{N C}$.

\subsection{Impact of projected climate change on building energy use}

Fig. 2 presents scatter plots of the $\mathrm{Q}_{\mathrm{NH}}$ and $\mathrm{Q}_{\mathrm{NC}}$ combinations for every calculated building energy model at eight studied locations for each of the four investigated periods. As expected, the results show that, in general, $\mathrm{Q}_{\mathrm{NH}}$ and $\mathrm{Q}_{\mathrm{NC}}$ are strongly affected by the projected climate change at each location. Observing Fig. 2 also reveals a general trend of the projected decrease in $\mathrm{Q}_{\mathrm{NH}}$ and increase in $\mathrm{Q}_{\mathrm{NC}}$ over time. In particular, in Athens, $\mathrm{Q}_{\mathrm{NH}}$ is projected to drop to $0 \mathrm{kWh} / \mathrm{m}^{2}$ in $1.7 \%$ of the calculated cases until 2080. In 2000 there were no such cases, although some building models had $\mathrm{Q}_{\mathrm{NH}}$ close to zero. In Milan and Ljubljana, a projected increase in $\mathrm{Q}_{\mathrm{NC}}$ demonstrates that in 2080 at both locations, it will no longer be possible to achieve $0 \mathrm{kWh} / \mathrm{m}^{2}$ of $\mathrm{Q}_{\mathrm{NC}}$ in residential buildings solely by using the studied passive design measures. In particular, at present (i.e. the 2000 period), there are $4 \%$ of building models in Ljubljana that have $\mathrm{Q}_{\mathrm{NC}}$ equal to zero, while in Milan in 2000 , there are already only $0.6 \%$ of such cases.

If the average value of $\mathrm{Q}_{\mathrm{T}}\left(=\mathrm{Q}_{\mathrm{NH}}+\mathrm{Q}_{\mathrm{NC}}\right)$ for the entire sample is observed in Fig. 3, it can be deduced that the projected climate change will have a positive effect on the overall energy use of buildings under cold and also temperate climates, such as Ljubljana and Berlin, and a negative effect in Athens. In Milan, Madrid and Porto, $\mathrm{Q}_{\mathrm{T}}$ 's average value for the entire sample will remain relatively similar throughout the century. Although $\mathrm{Q}_{\mathrm{NH}}$ and $\mathrm{Q}_{\mathrm{NC}}$ change over time in all the studied cases, which can be detected through the shift in the point clouds in Fig. 2, generally speaking, the cases in the 5th and the 95th percentiles (i.e. the best and the worst-performing 24,840 building models) are respectively less or more affected by the projected warming climate (Fig. 3).

The 5th percentile represents building models with the best combination of passive design measures regarding their energy efficiency and climate adaptability. In contrast, the highest $\mathrm{Q}_{\mathrm{T}}$ cases, namely the 95th percentile, will be more affected by the warming climate (Fig. 3). Therefore, a different conclusion can be drawn for each of the percentiles. For the 95th percentile, which consists of building models with the worst combination of passive measures, global warming will, on average, result in the highest decrease of $\mathrm{Q}_{\mathrm{T}}$ by the end of the century. The stated is valid for all the analysed locations, except Athens, where the $\mathrm{Q}_{\mathrm{T}}$ increase is the highest in the 95th percentile models. The latter exception is the consequence of the already warm climate getting even warmer, resulting in an above-average increase in overheating in the least climate-adapted building models. These are typically less thermally insulated buildings (i.e. high $\mathrm{U}_{\mathrm{O}}$ and $\mathrm{U}_{\mathrm{W}}$ values) having low DHC and $\mathrm{NV}_{\mathrm{C}}$, and at the same time high WFR and $\alpha_{\text {sol }}$. This specific combination of parameters results in high vulnerability to a warming climate.

On the other hand, the average $\mathrm{Q}_{\mathrm{T}}$ of building models in the 5 th percentile is typically less affected by climate change. However, the trend of change in $\mathrm{Q}_{\mathrm{T}}$ average values for the 5 th percentile during the 21st century at some locations (i.e. Athens, Madrid, Milan, Porto) contradicts the one observed for the entire sample. For the exposed locations, building models in the 5th percentile will exhibit an increase in average $\mathrm{Q}_{\mathrm{T}}$ during the 21st century, which means that the increase of $\mathrm{Q}_{\mathrm{NC}}$ has a more significant effect on $\mathrm{Q}_{\mathrm{T}}$ than the decrease of $\mathrm{Q}_{\mathrm{NH}}$ has at these locations for the buildings of the 5 th percentile.

Although climate change is projected to decrease most dramatically the $\mathrm{Q}_{\mathrm{T}}$ of building models in the 95th percentile, this change will be far smaller than the effect of making buildings more climate-adapted and thus more energy efficient. Designing a new 5th percentile building or energy retrofitting an existing building of the 95th percentile to get an 

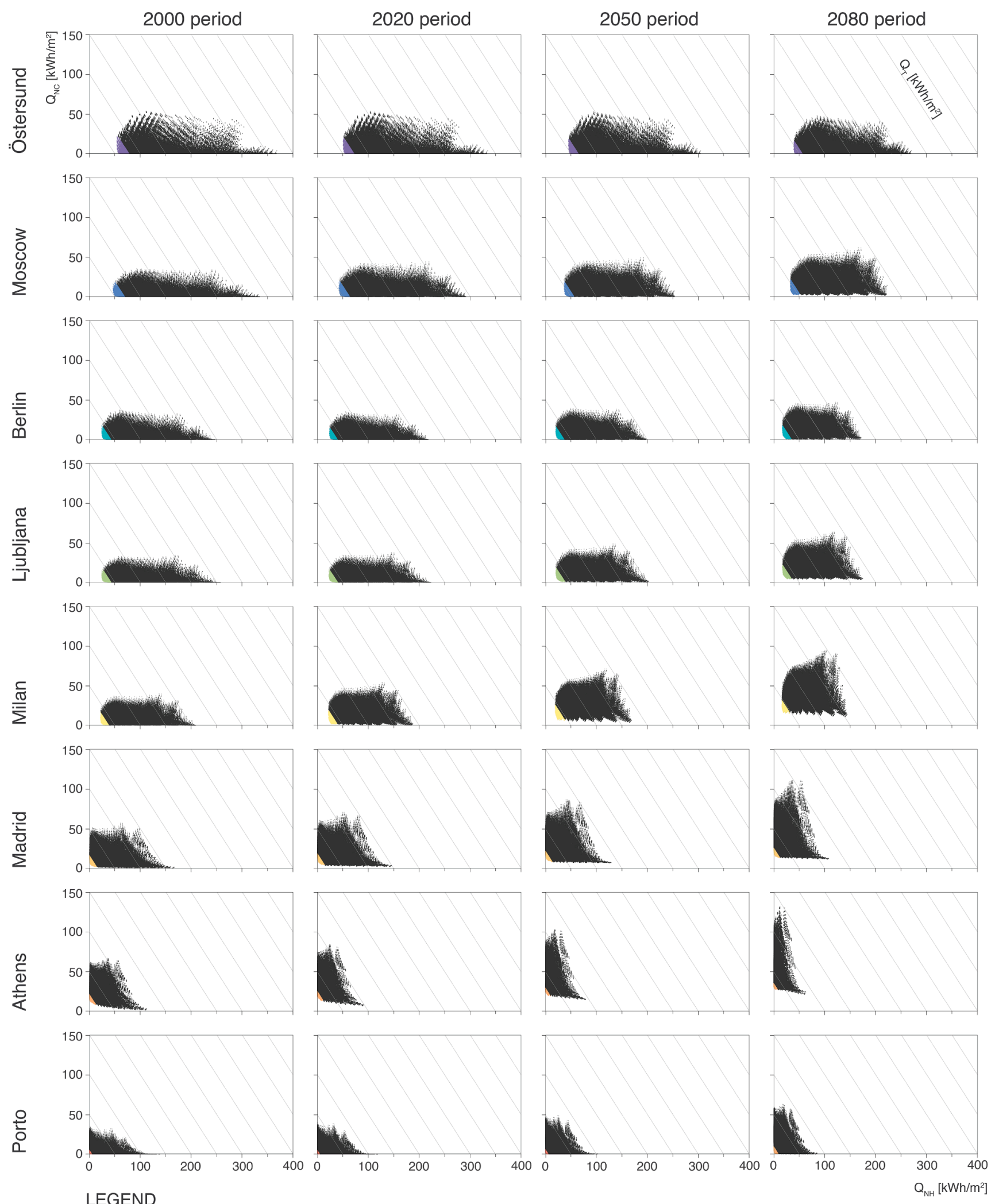

LEGEND

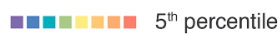

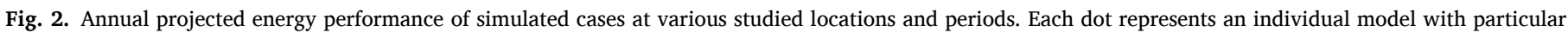

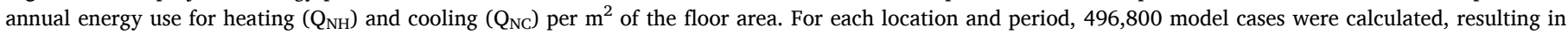
$15,897,600$ simulated cases. 

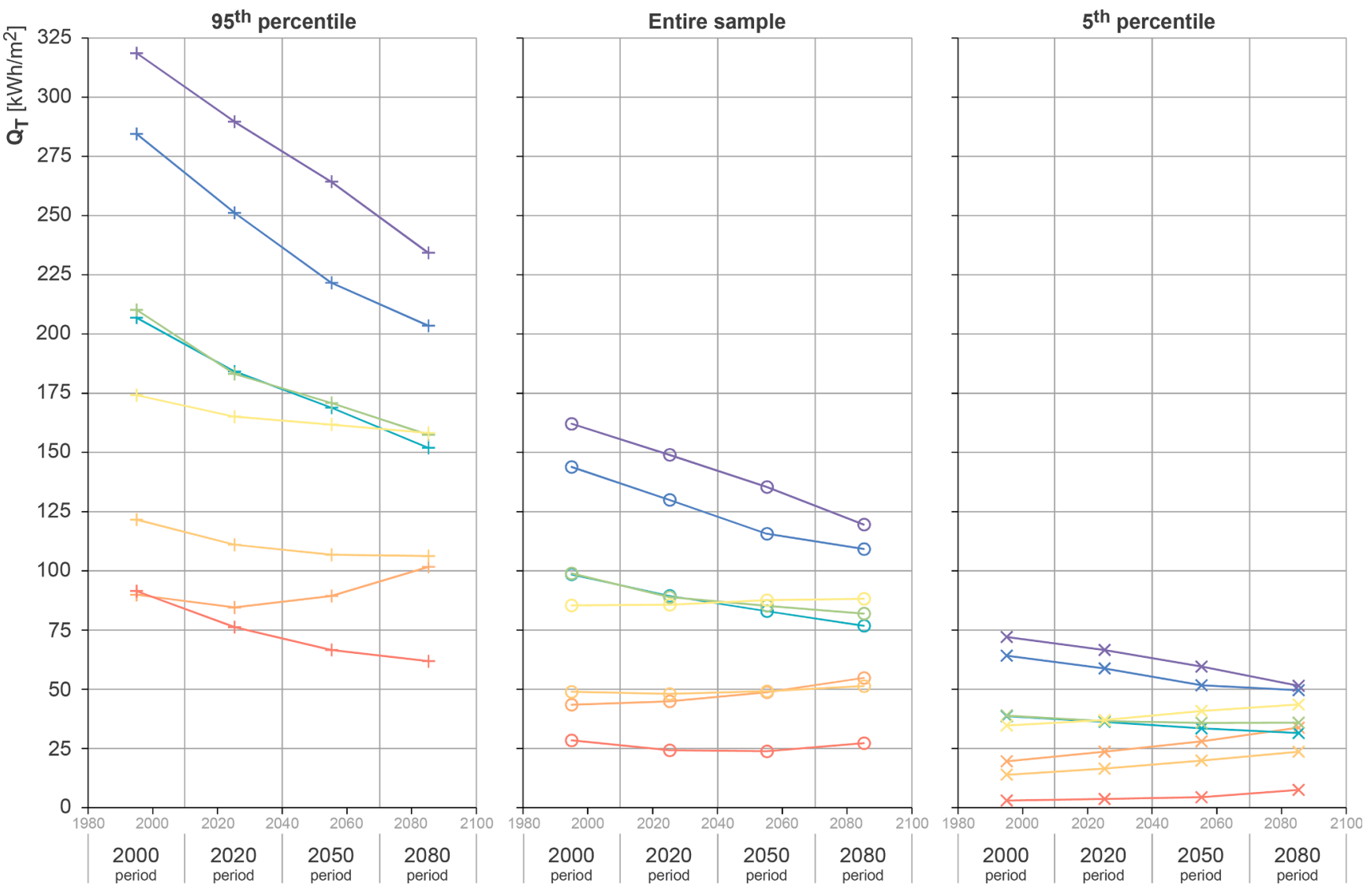

\footnotetext{
LEGEND

+ average of $95^{\text {th }}$ percentile (worst 24,840 cases)

O average of entire sample (all 496,800 cases)

$\times$ average of $5^{\text {th }}$ percentile (best 24,840 cases)
}
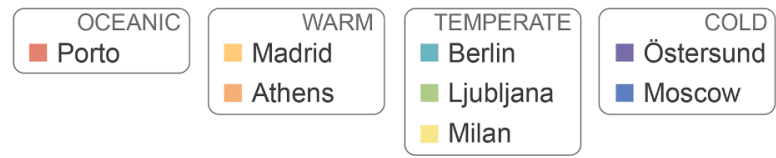

Fig. 3. Annual projected average $\mathrm{Q}_{\mathrm{T}}\left(=\mathrm{Q}_{\mathrm{NH}}+\mathrm{Q}_{\mathrm{NC}}\right)$ for the entire sample (middle), the 95 th percentile (left) and the 5 th percentile (right) at various studied locations and periods.

average building or even a 5 th percentile building will have a far greater effect on reducing $\mathrm{Q}_{\mathrm{T}}$ than the projected climate change effects. For this reason, the 5th percentile models (colour-coded in Fig. 2) were chosen for detailed analysis because they represent the most energy-efficient and the most climate-adapted examples and provide insight into the design measures required to achieve low $\mathrm{Q}_{\mathrm{T}}$ by simultaneously optimising both $\mathrm{Q}_{\mathrm{NH}}$ and $\mathrm{Q}_{\mathrm{NC}}$. According to $\mathrm{Q}_{\mathrm{T}}$, it is crucial to note that the 5 th percentile is characterised by promisingly low energy use for cooling and heating buildings. However, it also becomes evident that the relative importance of individual studied passive design measures and their resulting impact on $\mathrm{Q}_{\mathrm{NH}}$ and $\mathrm{Q}_{\mathrm{NC}}$ will change over time since the resulting $\mathrm{Q}_{\mathrm{T}}$ is significantly different until 2080 compared to the historical period of 2000 .

As identified above, a high level of buildings' energy efficiency can be achieved by applying the appropriate combination of the studied passive design measures. Therefore, the relationship between a projected climate change and characteristic values of $\mathrm{Q}_{\mathrm{NH}}, \mathrm{Q}_{\mathrm{NC}}$ and $\mathrm{Q}_{\mathrm{T}}$ (Fig. 4) for the 5th percentile was observed in greater detail. Fig. 4 shows that $\mathrm{Q}_{\mathrm{NH}}$ is highest in cold climates, such as Östersund and Moscow, and the lowest in warm climates, such as Madrid and Athens, and oceanic climates such as Porto. On the other hand, warm climates have the highest demand for $\mathrm{Q}_{\mathrm{NC}}$. Speaking in absolute terms, according to the reached $\mathrm{Q}_{\mathrm{T}}$ in 2000 , the energy use of the 5th percentile buildings is confidently below $80,70,45,45,40,20,25$ and $5 \mathrm{kWh} / \mathrm{m}^{2}$ in Östersund, Moscow, Berlin, Ljubljana, Milan, Madrid, Athens and Porto, respectively. Simultaneously, the min-max range of $\mathrm{Q}_{\mathrm{T}}, \mathrm{Q}_{\mathrm{NH}}$ and $\mathrm{Q}_{\mathrm{NC}}$ is narrower in warm locations (coloured bars in Fig. 4). In terms of climate change impact, in locations with warmer conditions (i.e. Athens, Madrid, Porto, Milan), $\mathrm{Q}_{\mathrm{T}}$ is projected to substantially increase until the end of the century, almost doubling the average $\mathrm{Q}_{\mathrm{T}}$ of the 5 th percentile in the instance of Madrid and Athens. A reverse trend applies to the colder locations of Ljubljana, Berlin, Moscow and Östersund, where $\mathrm{Q}_{\mathrm{T}}$ is projected to decrease, albeit to a smaller degree (e.g. average $\mathrm{Q}_{\mathrm{T}}$ for Östersund will be reduced approximately by $30 \%$ by 2080 in comparison to 2000). Although this trend may apply to all the mentioned locations, a turning point in the average $\mathrm{Q}_{\mathrm{T}}$ curve can be detected in Ljubljana, where a minimum projected total energy use would be reached sometime between 2020 and $2050\left(\mathrm{Q}_{\mathrm{T}, 2000}=28.2 \mathrm{kWh} / \mathrm{m}^{2}\right.$, $\mathrm{Q}_{\mathrm{T}, 2020}=27.2 \mathrm{kWh} / \mathrm{m}^{2}, \mathrm{Q}_{\mathrm{T}, 2050}=27.3 \mathrm{kWh} / \mathrm{m}^{2}, \mathrm{Q}_{\mathrm{T}, 2080}=28.1 \mathrm{kWh} /$ $\mathrm{m}^{2}$ ). In general terms, this means that the $\mathrm{Q}_{\mathrm{T}}$ of the 5 th percentile at the end of the century will still be highest in cold climates and lowest in warm and oceanic climates. However, the gap in the average $\mathrm{Q}_{\mathrm{T}}$ between the cold and warm locations will decrease substantially, while the ratio between $\mathrm{Q}_{\mathrm{NH}}$ and $\mathrm{Q}_{\mathrm{NC}}$ will also change significantly for all locations (Fig. 4). Both described trends signal a profound change in the building energy use patterns across Europe.

This phenomenon indicates that it is easier to achieve low $Q_{T}$ in temperate and warm locations solely by using passive measures than in colder climates. However, in warm and some temperate climates, by 2080, the situation is projected to change towards higher $\mathrm{Q}_{\mathrm{T}}$ regardless 

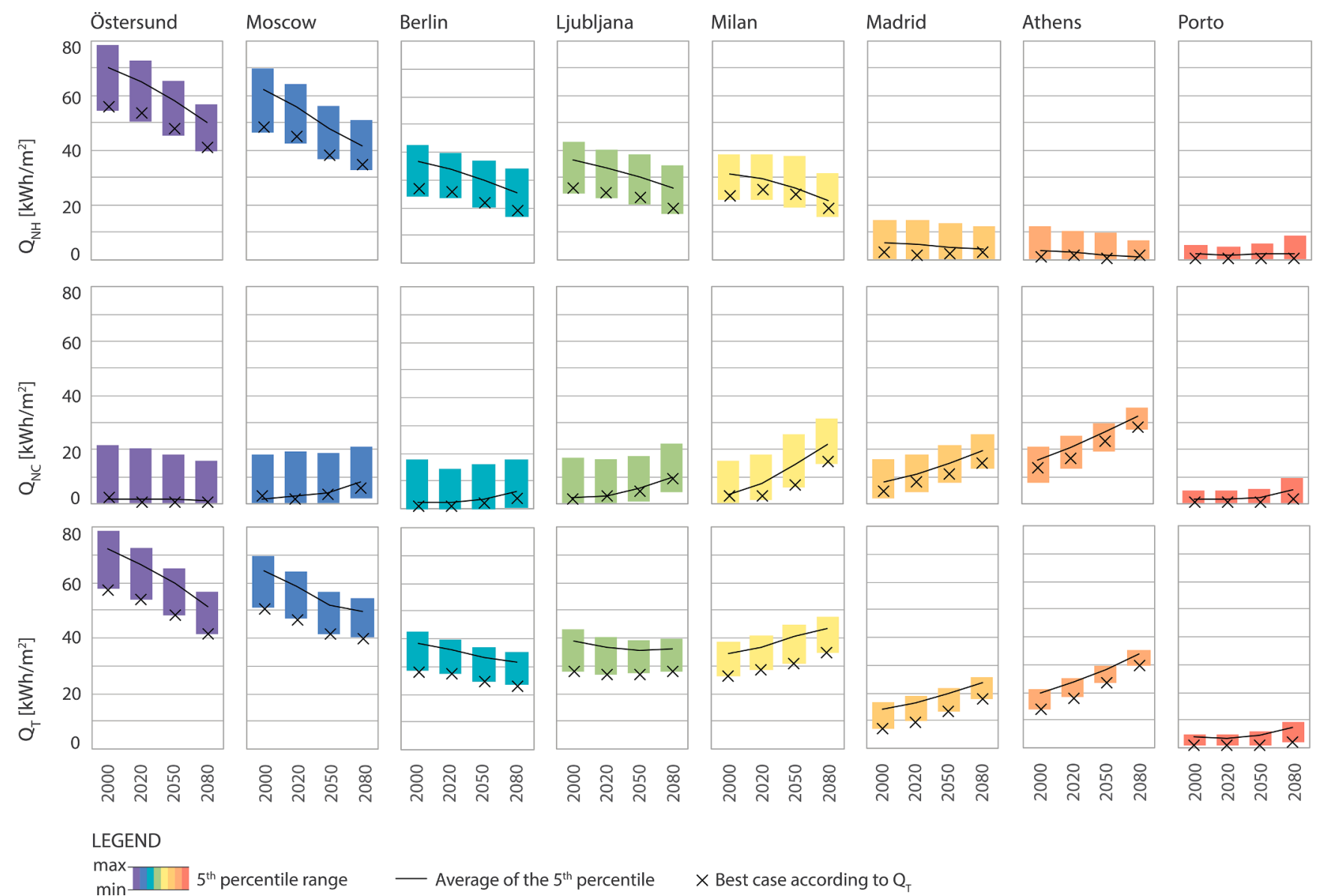

- Average of the $5^{\text {th }}$ percentile

$\times$ Best case according to $\mathrm{Q}_{\mathrm{T}}$

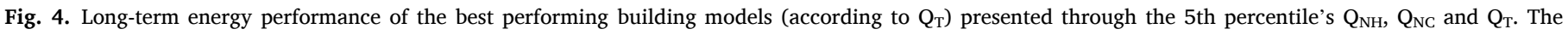
coloured bars demonstrate the energy use range, while the black lines show the average value for the building models in the 5th percentile.

of the used passive measures (see Fig. 4).

\subsection{Impact of individual passive design measure on energy use}

To gain insight into the impact of passive design measures at each location and for every future time slice, a quantitative analysis was performed for the 5 th percentile using descriptive statistics. The results can be seen in Figs. 5-7.

\subsubsection{Opaque envelope thermal transmittance $\left(U_{O}\right)$}

Fig. 5 shows that the range of applicable $U_{O}$ values in the 5 th percentile is wider in warm climates than in temperate and cold climates. Therefore, to achieve the lowest $5 \%$ of $\mathrm{Q}_{\mathrm{T}}$, in extremely cold locations, such as Östersund, $\mathrm{U}_{\mathrm{O}}$ of $0.15 \mathrm{~W} / \mathrm{m}^{2} \mathrm{~K}$ or lower should be used. In contrast, in another cold (Moscow) and temperate (Berlin, Ljubljana, Milan) climates, $\mathrm{U}_{\mathrm{O}}$ of $0.20 \mathrm{~W} / \mathrm{m}^{2} \mathrm{~K}$ or lower is necessary. For warm climates, the same analysis shows that in order for a building to be in the 5 th percentile, according to $\mathrm{Q}_{\mathrm{T}}$, its $\mathrm{U}_{\mathrm{O}}$ should not exceed $0.30 \mathrm{~W} /$ $\mathrm{m}^{2} \mathrm{~K}$. However, even under warm (i.e. Madrid and Athens) and oceanic (i.e. Porto) climates, the average $\mathrm{U}_{\mathrm{O}}$ of the models in the 5 th percentile is lower than $0.15 \mathrm{~W} / \mathrm{m}^{2} \mathrm{~K}$, with a noticeable increase towards the end of the 21 st century (Fig. 5). The average $U_{O}$ value is lowest in cold locations and highest in warm and oceanic climates. Nevertheless, the 5th percentile analysis results demonstrated that low $\mathrm{U}_{\mathrm{O}}$ values $(<0.15 \mathrm{~W} /$ $\mathrm{m}^{2} \mathrm{~K}$ ) are beneficial for the energy performance of the climate-adapted buildings regardless of the climate type. The only difference is that slightly higher $\mathrm{U}_{\mathrm{O}}$ values can be used under warmer climates, giving designers in such climate types more freedom of choice in developing their designs. According to $\mathrm{Q}_{\mathrm{T}}$, the $\mathrm{U}_{\mathrm{O}}$ value of the best case is for all the locations and all periods at $0.10 \mathrm{~W} / \mathrm{m}^{2} \mathrm{~K}$, namely at its lowest analysed value. The average $\mathrm{U}_{\mathrm{O}}$ value in the 5 th percentile gradually increases towards the end of the century for all the analysed locations. The stated signals a trend indicating that in the future high energy efficiency, i.e. low $\mathrm{Q}_{\mathrm{T}}$, will be achievable on average with slightly higher $\mathrm{U}_{\mathrm{O}}$ values than today.

\subsubsection{Window thermal transmittance $\left(U_{W}\right)$}

A similar observation can be made for the thermal transmittance of windows $\left(\mathrm{U}_{\mathrm{W}}\right)$, where unexpectedly, even relatively high $\mathrm{U}_{\mathrm{W}}$ values of up to $2.40 \mathrm{~W} / \mathrm{m}^{2} \mathrm{~K}$ can be found in the 5 th percentile building models for all locations (Fig. 5). However, in the building models of the 5th percentile, high $\mathrm{U}_{\mathrm{W}}$ (i.e. $2.40 \mathrm{~W} / \mathrm{m}^{2} \mathrm{~K}$ ) is always combined with lower WFRs (below $10 \%$ in cold or below $20 \%$ in a warm climate) and minimal $\mathrm{U}_{\mathrm{O}}$ values (i.e. $0.10 \mathrm{~W} / \mathrm{m}^{2} \mathrm{~K}$ in a cold or $0.20 \mathrm{~W} / \mathrm{m}^{2} \mathrm{~K}$ and lower in a warm climate). Similarly, as for the $U_{\mathrm{O}}$, the average $\mathrm{U}_{\mathrm{W}}$ value is lowest for cold locations and highest in warm and oceanic climates. Nevertheless, the average $\mathrm{U}_{\mathrm{W}}$ is always below $1.30 \mathrm{~W} / \mathrm{m}^{2} \mathrm{~K}$, regardless of location and period. The change in the average $\mathrm{U}_{\mathrm{W}}$ values of the 5 th percentile concerning the projected climate change is similar to that of the $\mathrm{U}_{\mathrm{O}}$. It means that the average $\mathrm{U}_{\mathrm{W}}$ values are projected to steadily increase throughout the century with an increment of 0.01 to $0.10 \mathrm{~W} / \mathrm{m}^{2}$ K (i.e. $\Delta \mathrm{U}_{\mathrm{W} \text {,cold }} \approx 0.04-0.10 \mathrm{~W} / \mathrm{m}^{2} \mathrm{~K}, \Delta \mathrm{U}_{\mathrm{W} \text {,temperate }} \approx 0.09-0.10 \mathrm{~W} / \mathrm{m}^{2}$ $\mathrm{K}, \Delta \mathrm{U}_{\mathrm{W}, \text { warm }} \approx 0.01-0.04 \mathrm{~W} / \mathrm{m}^{2} \mathrm{~K}, \Delta \mathrm{U}_{\mathrm{W} \text {,oceanic }} \approx 0.07 \mathrm{~W} / \mathrm{m}^{2} \mathrm{~K}$ ) when comparing the 2000 and 2080 periods. The best case's $U_{\mathrm{W}}$ value is for all the locations and all periods at $0.60 \mathrm{~W} / \mathrm{m}^{2} \mathrm{~K}$, namely at its lowest analysed value. 

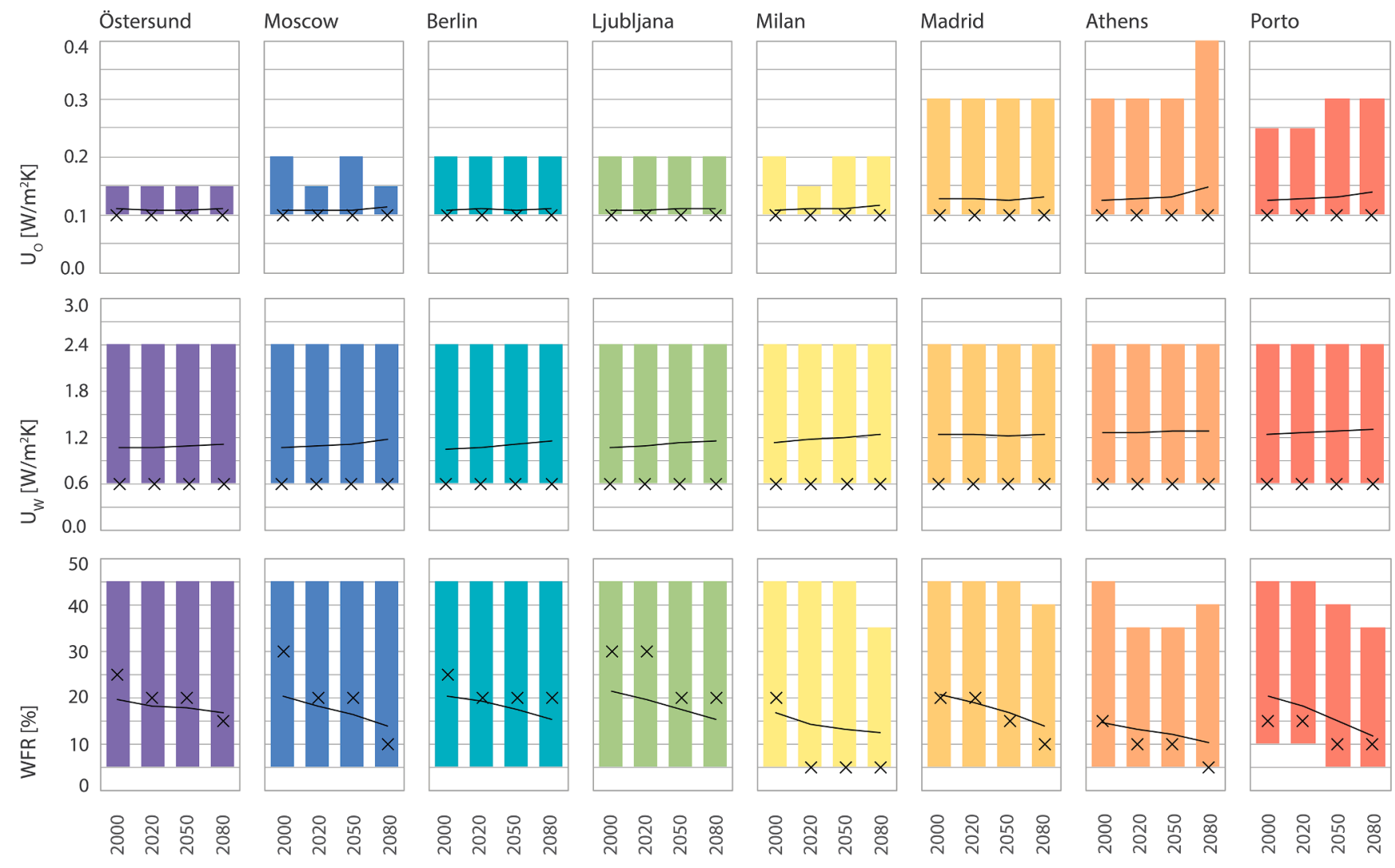

유유유 융

\section{LEGEND \\ $\max \quad 5^{\text {th }}$ percentile range \\ - Average of the $5^{\text {th }}$ percentile \\ $\times$ Best case according to $Q_{T}$}

Fig. 5. Characteristic values of $U_{O}, U_{W}$ and WFR represented in the 5th percentile according to $Q_{T}$. The coloured bars demonstrate the parameter range, while the black lines show the average value for the building models in the 5 th percentile.

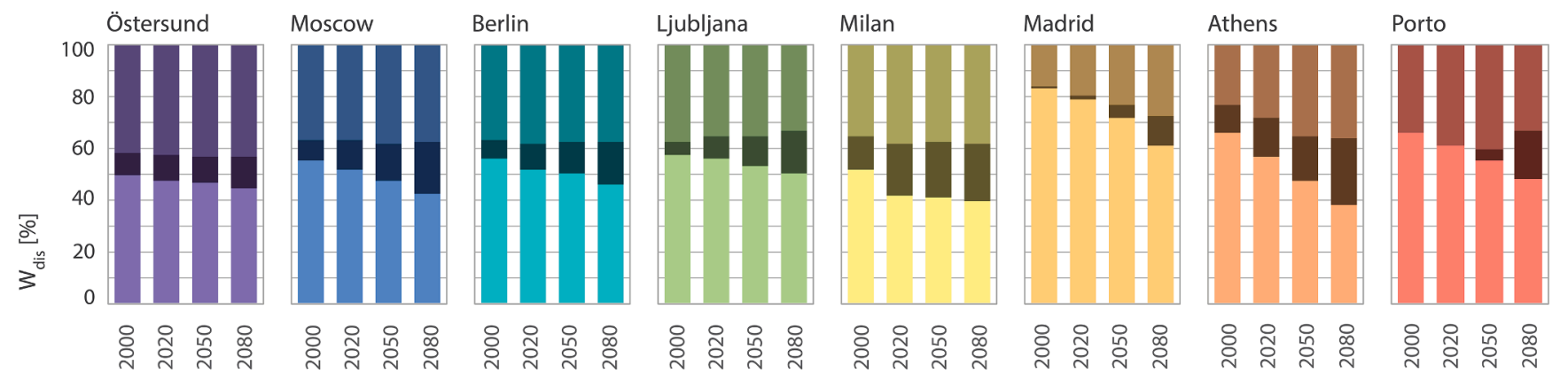
LEGEND

Share of cases with south-concentrated windows (WFR $>5 \%$ )
Share of cases with equal area of windows at all orientations (WFR $=5 \%$, i.e. “base" case)
Share of cases with equal area of windows at all orientations (WFR $>5 \%$ )

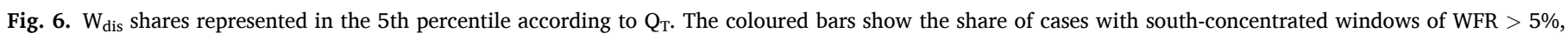

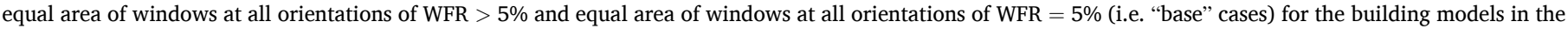
5 th percentile.

\subsubsection{Window to floor ratio (WFR)}

For cold and temperate locations, the analysis showed that it would be possible to achieve the 5 th percentile $\mathrm{Q}_{\mathrm{T}}$ by using any of the analysed WFRs, namely 5-45\%, during all periods. In contrast, in warm and oceanic climates, the WFR maximum value in the second half of the century is limited to 35 or $40 \%$. Furthermore, in the oceanic climate (i.e. Porto), the WFR for 2000 and 2020 is also limited to minimum values (Fig. 5). Be that as it may, for building models with a WFR of $45 \%$, in cold locations (e.g. Östersund), $\mathrm{U}_{\mathrm{W}}$ needs to be $0.8 \mathrm{~W} / \mathrm{m}^{2} \mathrm{~K}$ or lower and combined with $\mathrm{U}_{\mathrm{O}}$ equal to $0.15 \mathrm{~W} / \mathrm{m}^{2} \mathrm{~K}$ or less. In temperate climates (e.g. Ljubljana), the maximum WFRs are achievable with $\mathrm{U}_{\mathrm{W}}$ of $1.0 \mathrm{~W} /$ $\mathrm{m}^{2} \mathrm{~K}$ or less and $\mathrm{U}_{\mathrm{O}}$ below $0.15 \mathrm{~W} / \mathrm{m}^{2} \mathrm{~K}$, while in a warm climate (e.g. Athens), $\mathrm{U}_{\mathrm{W}}$ should not be higher than $0.6 \mathrm{~W} / \mathrm{m}^{2} \mathrm{~K}$. In the latter case of locations with a warm climate, such high WFR resulted in only two cases out of the whole sample of the 5th percentile. Indeed, one should be aware that such a choice may result in a predominately cooling dominated building. However, any $\mathrm{U}_{\mathrm{W}}$ can be used for WFRs up to $20 \%$ in temperate and warm locations (e.g. Ljubljana, Athens) and up to $15 \%$ in 


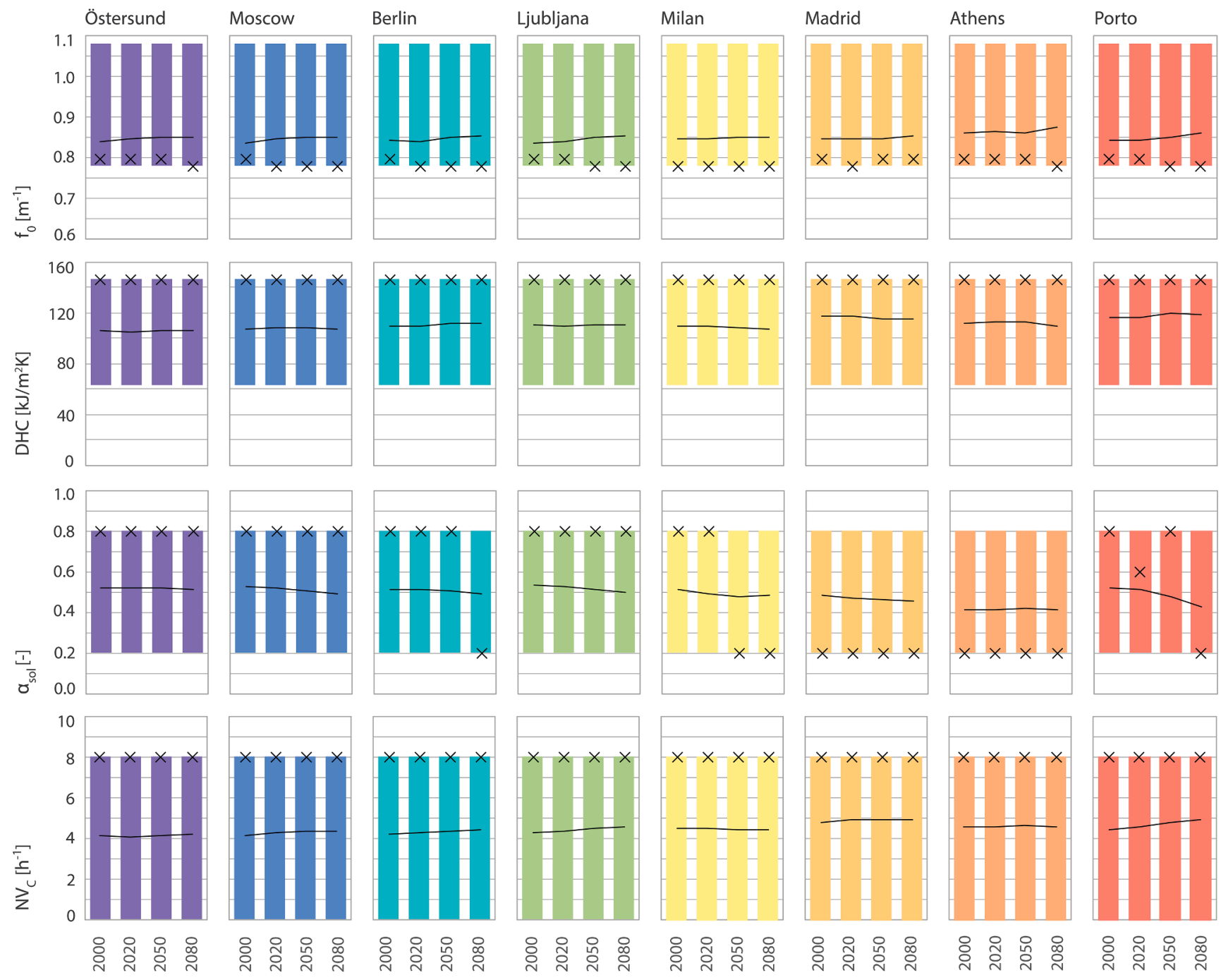

LEGEND

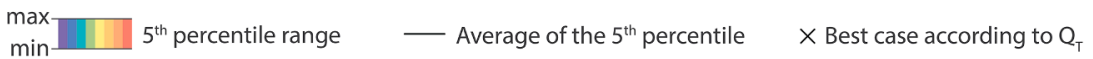

Fig. 7. Characteristic values of $\mathrm{f}_{0}$, DHC, $\alpha_{\mathrm{sol}}$ and $\mathrm{NV}_{\mathrm{c}}$ represented in the 5 th percentile of $\mathrm{Q}_{\mathrm{T}}$. The coloured bars demonstrate the parameter range, while the black lines show the average value for the building models in the 5th percentile.

cold locations (e.g. Östersund). The influence of WFR on the resulting $\mathrm{Q}_{\mathrm{T}}$ of the 5 th percentile is probably most affected by the projected climate change, which can be seen by observing WFR ranges and average values in Fig. 5. To demonstrate, observing the 5th percentile WFR average value trend until 2080 shows that they will substantially decrease at all the analysed locations, with the most significant decrease of 8.6 percentage points in Porto and the slightest change of 2.8 percentage points for Östersund. In Porto, the "average optimal" WFR is projected to shift from $20.3 \%$ to $11.7 \%$, a decrease of 8.6 percentage points. Simultaneously, even in Östersund, where the decrease in WFR is the smallest, the "average optimal" WFR is projected to shift from $19.5 \%$ to $16.7 \%$, a change of 2.9 percentage points. WFR is the only studied parameter that displays a constant projected decrease in its value for the best case at all locations and all periods (Fig. 5).

\subsubsection{Distribution of windows ( $W_{\text {dis }}$ )}

The share of building models with south-concentrated widows and WFR above 5\% regarding the total number of building models of the 5th percentile can be seen in Fig. 6. This share is higher for warm and oceanic locations than for cold and temperate locations. Choosing southconcentrated windows allows using higher than average $U_{O}$ values under temperate (e.g. Ljubljana) and cold climates (e.g. Moscow), namely $0.20 \mathrm{~W} / \mathrm{m}^{2} \mathrm{~K}$, as well as in warm climates (e.g. Athens), namely $0.30 \mathrm{~W} / \mathrm{m}^{2} \mathrm{~K}$. "Base" cases with an equally distributed 5\% WFR usually perform best only when combined with $\mathrm{U}_{\mathrm{O}}$ of $0.10 \mathrm{~W} / \mathrm{m}^{2} \mathrm{~K}$ due to an increased influence of the thermal characteristics of the opaque building envelope on the resulting final $\mathrm{Q}_{\mathrm{T}}$. Observing the $\mathrm{W}_{\mathrm{dis}}$ shares shows that for a building to be included in the 5 th percentile of $\mathrm{Q}_{\mathrm{T}}$, the share of south-concentrated cases decreases over time due to the projected climate change. In particular, at many locations, the number of cases with south-concentrated windows drops below $50 \%$ by the 2080 time period. Simultaneously, the share of "base" cases is on the rise for all the locations, indicating that south-concentrated glazing is becoming a burden due to the increased overheating.

\subsubsection{Shape factor $\left(f_{0}\right)$}

Data presented in Fig. 7 show that, as it could be expected, the average value of $\mathrm{f}_{0}$ for buildings in the 5 th percentile according to $\mathrm{Q}_{\mathrm{T}}$ is lower in cold climates and higher in warm and oceanic climates. Nevertheless, at all the locations, any of the analysed building shapes can be used and still result in a low enough $\mathrm{Q}_{\mathrm{T}}$ to be included in the 5th percentile. In cold locations, lower $\mathrm{U}_{\mathrm{O}}$ application (e.g. $0.10 \mathrm{~W} / \mathrm{m}^{2} \mathrm{~K}$ ) 
allows for higher $f_{0}$ (e.g. a semi-enclosed atrium). The same is true for warm locations (e.g. Athens), but there the value of $U_{O}$ can be up to 0.20 $\mathrm{W} / \mathrm{m}^{2} \mathrm{~K}$ when choosing a non-compact building shape. For all locations, the average $f_{0}$ values increase until the 2080 time period. However, in terms of $\mathrm{Q}_{\mathrm{T}}$, the best case usually has an $\mathrm{f}_{0}$ equal to 0.796 (i.e. a semicompact building shape), with a slight tendency to shift towards a compact building shape (i.e. $\mathrm{f}_{0}=0.778$ ) with the progression of time.

\subsubsection{Diurnal heat storage capacity (DHC)}

Considering the DHC (Fig. 7), it can be said that although the average DHC $\left(\approx 110 \pm 5 \mathrm{~kJ} / \mathrm{m}^{2} \mathrm{~K}\right)$ of the 5 th percentile is somewhere between a medium (e.g. brick) and a heavy (e.g. concrete or stone) weight construction, all the analysed DHCs can be used to reach the 5th percentile $\mathrm{Q}_{\mathrm{T}}$ energy use at all the locations and during all periods. The latter is primarily the result of the ability to offset the undesirable impact of low DHC (i.e. $63 \mathrm{~kJ} / \mathrm{m}^{2} \mathrm{~K}$ ) on the resulting $\mathrm{Q}_{\mathrm{T}}$ by using low values of $\mathrm{U}_{\mathrm{O}}$. However, to achieve the 5 th percentile of $\mathrm{Q}_{\mathrm{T}}$ in temperate (e.g. Ljubljana) and cold (Östersund, Moscow) climates, $\mathrm{U}_{\mathrm{O}}$ must be $0.15 \mathrm{~W} / \mathrm{m}^{2} \mathrm{~K}$ or lower if choosing a lightweight timber construction (i.e. $\mathrm{DHC}=63$ $\mathrm{kJ} / \mathrm{m}^{2} \mathrm{~K}$ ). Similarly, $\mathrm{U}_{\mathrm{O}}$ must be equal to or below $0.20 \mathrm{~W} / \mathrm{m}^{2} \mathrm{~K}$ in Athens when using lightweight timber construction.

\subsubsection{External surface solar absorptivity $\left(\alpha_{s o l}\right)$}

In Fig. 7, the characteristic values of $\alpha_{\text {sol }}$ can be seen, where similar as for other parameters, any of the analysed values (i.e. 0.2, 0.4, 0.6 and 0.8 ) can be used to achieve the 5 th percentile of $Q_{T}$. Nonetheless, in the case of warm climates (e.g. Athens), $\alpha_{\text {sol }}$ equal to 0.2 can be used in all the cases, while higher values are limited by applying lower $\mathrm{U}_{\mathrm{O}}$, namely $\alpha_{\text {sol }}$ of 0.8 , can only be used with $U_{O}$ equal to or lower than $0.20 \mathrm{~W} / \mathrm{m}^{2} \mathrm{~K}$. The opposite is true for temperate climate locations (e.g. Ljubljana, Milan), where $\alpha_{\text {sol }}$ equal to 0.2 can only be used with $U_{O}$ equal to or lower than $0.15 \mathrm{~W} / \mathrm{m}^{2} \mathrm{~K}$, while $\alpha_{\mathrm{sol}}=0.8$ is acceptable in all the cases inside the 5 th percentile. Observing the $\alpha_{\text {sol }}$ values in future climate projections shows that the average value is steadily decreasing. The projected decrease in the average $\alpha_{\text {sol }}$ is less noticeable in cold and more pronounced in warm but above all in oceanic climates.

\subsubsection{Summer natural ventilation cooling rate $\left(N V_{C}\right)$}

Lastly, observing the $\mathrm{NV}_{\mathrm{C}}$ parameter results in the 5 th percentile (Fig. 7) shows that, as expected, higher average $N V_{C}$ values are found for warm and lower in temperate and cold locations. Using any $\mathrm{NV}_{\mathrm{C}}$ value can result in the $\mathrm{Q}_{\mathrm{T}}$ of a building model that falls inside the 5th percentile. However, a more in-depth analysis of the results showed that higher $\mathrm{NV}_{\mathrm{C}}$ rates are generally used in cases where external opaque surfaces are characterised by higher $\alpha_{\text {sol }}$ (i.e. 0.6 and 0.8 ) in all the locations. Additionally, more models with a lower DHC were included in the 5 th percentile when a non-zero $\mathrm{NV}_{\mathrm{C}}$ was simultaneously used (i.e. $\geq$ $1 \mathrm{~h}^{-1}$ ). For all the locations, the average $\mathrm{NV}_{\mathrm{C}}$ value of the 5 th percentile is gradually rising towards the end of the century, which is a logical consequence of a warming climate trend. In brief, any non-zero $\mathrm{NV}_{\mathrm{C}}$ value will effectively decrease $Q_{T}$, but the extent is limited by climate characteristics and the ratio between cooling and heating energy use since $\mathrm{NV}_{\mathrm{C}}$ only affects the $\mathrm{Q}_{\mathrm{NC}}$ values.

\section{Discussion}

The study aimed to evaluate the effectiveness of the selected passive building design measures and their ability to influence building energy use concerning projected climate change. This evaluation was achieved through a comprehensive parametric study, with a further in-depth analysis of the best performing $5 \%$ of building models (i.e. the 5 th percentile). In our opinion, this approach to finding optimum building configuration is better than the construction of Pareto fronts as it gives a higher number of potential candidates with still acceptable low energy use. Unlike optimisation, the most significant asset of the selected approach is that not just the global or local minimums are found, but also numerous neighbouring solutions are detected, still resulting in a low-energy building. Therefore, a vast pool of candidates is acquired without affecting the precision of the results. However, such an approach has some drawbacks: significantly longer calculation times and a need for a mindful insight by the assessor.

\subsection{The effect of passive design measures on building energy efficiency under climate change}

The results demonstrate that building energy use can be effectively regulated by passive design measures, while several parameter combinations resulted in an impressive or at least satisfactory energy efficiency level. The latter is expressed by the energy use results for the 5th percentile according to $\mathrm{Q}_{\mathrm{T}}$, where at numerous locations, a relatively low energy use rate was achieved by passive measures only, for example, $\mathrm{Q}_{\mathrm{T}}$ below $20 \mathrm{kWh} / \mathrm{m}^{2}$ in warm and below $40 \mathrm{kWh} / \mathrm{m}^{2}$ in temperate climates. However, the results show that even if the most favourable combination of the proposed passive design measures is used at any of the analysed locations, the impact of climate change on buildings' thermal performance will be difficult to neutralise. In other words, the calculated $\mathrm{Q}_{\mathrm{T}}$ of a building will inevitably be affected by the warming climate, resulting in either higher or lower energy use in comparison to the historical climate (i.e. 2000 period) and a substantially different ratio between cooling and heating energy demand. That is an important outcome in the context of building resilience. Nonetheless, while the stated might not be considered a problem in cold locations, where $\mathrm{Q}_{\mathrm{T}}$ is in general projected to decrease with an only slight increase in $\mathrm{Q}_{\mathrm{NC}}$, it represents a significant issue for buildings under temperate, oceanic and warm climates. For these locations, $\mathrm{Q}_{\mathrm{T}}$ is, in general, projected to increase, and the increment cannot be effectively counterbalanced by modifying the parameters of the studied passive design measures. In this perspective, Attia and Gobin [69] warned that even thermal adaptation strategies, such as clothing level and human thermal comfort adaptation, cannot suppress the effect of global warming. Therefore, the results provide crucial information for designing energy-efficient buildings that strive for climate adaptation and provide a general outlook for policymakers.

Moreover, the results section brings several values of the studied passive design measures, which are recommended to be practised when designing low energy buildings in each evaluated climate type. Besides, for some parameters, potential counterbalances are defined. For example, low DHC can be compensated by using very low $\mathrm{U}_{\mathrm{O}}$. Similar compensation can be made when applying high WFRs or high $\alpha_{\text {sol }}$ of the opaque building envelope. The study shows that in order to optimise (i. e. reduce) $Q_{T}$ of future buildings, slightly higher $\mathrm{U}_{\mathrm{O}}, \mathrm{U}_{\mathrm{W}}, \mathrm{f}_{0}, \mathrm{DHC}$ and $\mathrm{NV}_{\mathrm{C}}$ and a slightly lower $\alpha_{\text {sol }}$ should be used. Be that as it may, there is no need for any substantial change in the current optimal value of these parameters to achieve the lowest of $\mathrm{Q}_{\mathrm{T}}$ also in the future. On the other hand, in future, considerably lower WFRs, than those in contemporary energy-efficient buildings should be used. However, considering WFR, the results should be interpreted to acknowledge its impact on daylighting and view as well as the corresponding occupant preferences.

\subsection{Long-term climate adaptation of the best case models}

For each period, the best building model (i.e. an absolute optimum) with the lowest $\mathrm{Q}_{\mathrm{T}}$ for that period was identified. Given the effects of projected climate change on buildings' energy use and energy efficiency, there has been a broad debate in the literature about how buildings can be optimised to achieve long-term climate adaptation. This issue was further investigated in the study of the effects of passive design measures on climate adaptation. The results are presented in Fig. 8, where the long-term development of energy performance for an absolute best case among building models can be observed for each particular period and each location.

Fig. 8 shows that cold locations (i.e. Östersund and Moscow) could 


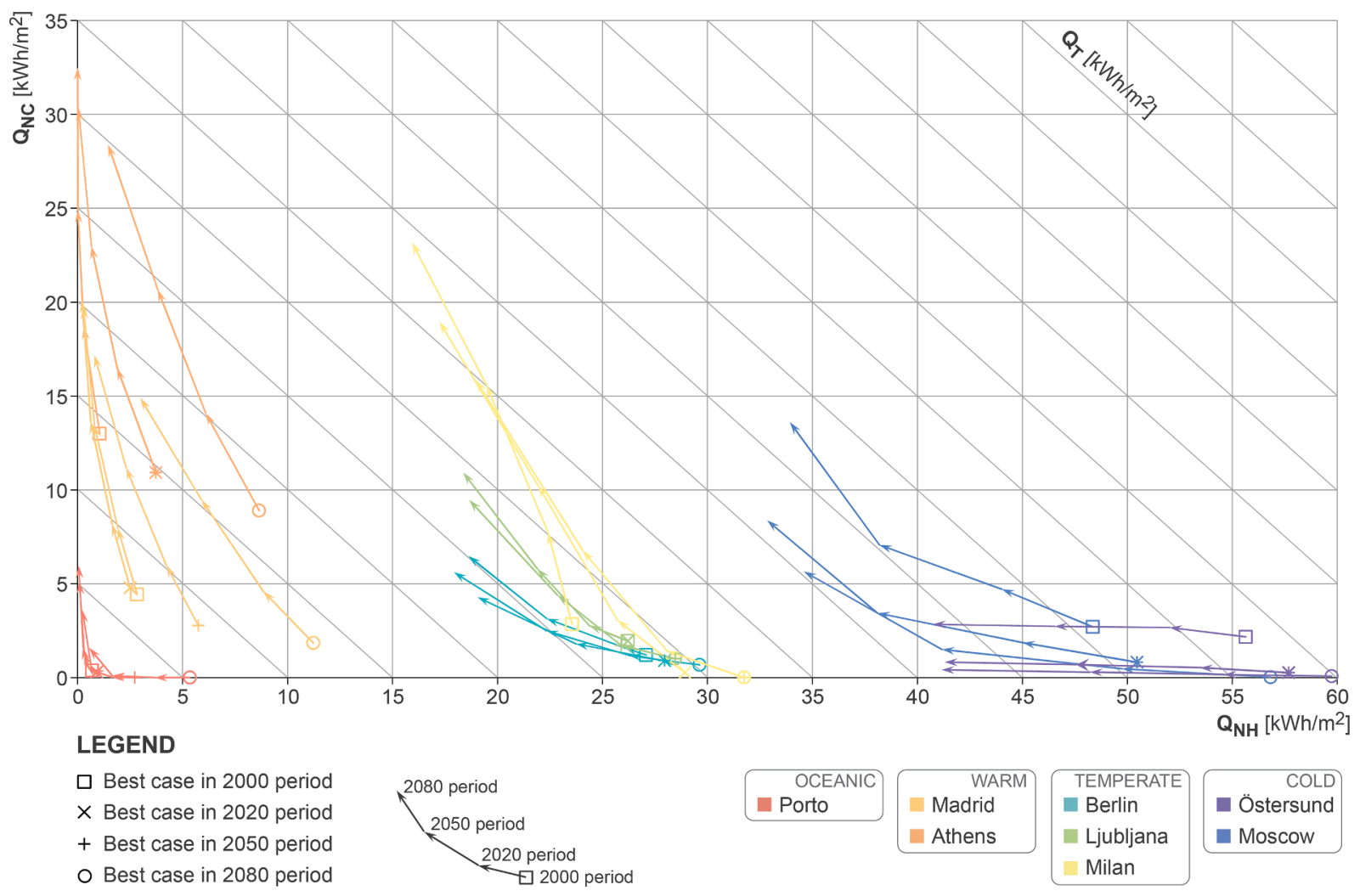

Fig. 8. Long-term development of energy performance of each best case according to $Q_{T}$.

benefit from the warming climate since $Q_{T}$ is projected to drastically decrease regardless of the period to which a building is optimised. If a residential building was built in Östersund in 2020 according to the optimum defined by the climate data for the 2000 period, after 50 years, it would cumulatively use $425.6 \mathrm{MWh}$ of energy with a ratio between heating and cooling energy use $\left(\mathrm{Q}_{\mathrm{NH}} / \mathrm{Q}_{\mathrm{NC}}\right)$ of 18 . If opting for the 2020/ 2050 period optimum, cumulative energy use would be 418.3 MWh $\left(\mathrm{Q}_{\mathrm{NH}} / \mathrm{Q}_{\mathrm{NC}}=80\right)$ and $422.1 \mathrm{MWh}\left(\mathrm{Q}_{\mathrm{NH}} / \mathrm{Q}_{\mathrm{NC}}=214\right)$ if going for the 2080 period optimum.

On the other hand, $\mathrm{Q}_{\mathrm{T}}$ of the best case in warm and some temperate locations (i.e. Athens, Madrid and Milan) is projected to significantly increase, so that buildings at such locations will use considerably more energy than in the current situation. If we look at the example of a residential building built in 2020 in Athens, after 50 years, the building will consume $185.5 \mathrm{MWh}$ of energy $\left(\mathrm{Q}_{\mathrm{NH}} / \mathrm{Q}_{\mathrm{NC}}=0.006\right)$ if opting for the 2000 period optimum, 177.3 MWh $\left(\mathrm{Q}_{\mathrm{NH}} / \mathrm{Q}_{\mathrm{NC}}=0.057\right)$ if deciding on the $2020 / 2050$ period optimum and $187.7 \mathrm{MWh}\left(\mathrm{Q}_{\mathrm{NH}} / \mathrm{Q}_{\mathrm{NC}}=0.265\right)$ if going for the 2080 period optimum.

In some cases, such as Berlin and Ljubljana, $Q_{T}$ does not appear to be significantly affected or dependent on the optimisation period. However, the $Q_{N H} / Q_{N C}$ ratios in these locations will be affected. The same example of a residential building as above, built in Ljubljana in 2020, would use after 50 years $226.9 \mathrm{MWh}$ of energy $\left(\mathrm{Q}_{\mathrm{NH}} / \mathrm{Q}_{\mathrm{NC}}=5.0\right)$ if opting for the 2000/2020 period optimum and 226.4 MWh (Q $\mathrm{Q}_{\mathrm{NH}} /$ $\mathrm{Q}_{\mathrm{NC}}=7.3$ ) if choosing the $2050 / 2080$ period optimum. In general, it is clear that in all the locations, except Milan, in the context of cumulative $\mathrm{Q}_{\mathrm{T}}$, it is best to design a new building according to the mid-term optimum (i.e. the $2020 / 2050$ period). Milan is the only case where the best set of parameters is achieved using the best case for the 2080 period.

It is important to note that even if the above-described energy use indicates that for some locations, the design of a building according to climate change projections does not have a significant impact on the resulting cumulative $\mathrm{Q}_{\mathrm{T}}$, the energy use and heating to cooling energy use ratios are shown for the absolute best cases only. It means that such building models represent one of the best climate-resilient building designs possible. At this point, it also has to be stressed that choosing the long-term optimum building design is not as easy as just choosing a set of passive design measures that would lead to the lowest $\mathrm{Q}_{\mathrm{T}}$ but is somewhat more complicated. Since the warming climate will result in lower $\mathrm{Q}_{\mathrm{NH}} / \mathrm{Q}_{\mathrm{NC}}$ ratios and higher $\mathrm{Q}_{\mathrm{NC}}$ use, the building energy performance optimisation must be a thorough process. Higher $\mathrm{Q}_{\mathrm{NC}}$ results in progressively higher electricity consumption for cooling, which is particularly worrisome [70] due to increased peak demand. If more and more buildings become actively cooled during summer or even in spring and autumn, it will lead to a significantly different energy demand for building operation - the energy demand for which energy suppliers may not be prepared.

\subsection{Study limitations}

The results of the study must be interpreted within the framework of applicable limitations. The primary limitation to the generalisation of the presented results is that the floor area and the corresponding volume and shape of the analysed building models were devised according to the statistical average of the EU. We are clearly aware that such a sample represents residential buildings in the EU but has limitations in applying the derived results to specific countries or building. Therefore, the study's findings should be used with caution when used as guidelines for the performance of buildings that have much smaller or much larger floor areas or are, in any case, geometrically considerably different. Second, several input parameters for energy models were set constant, limiting our study primarily to passive building envelope elements and natural ventilation. Shading of the transparent elements was set constant since it was recognised by our previous findings (see refs. $[7,71]$ ) as one of the crucial actions to control overheating at present and in future. Of course, we are aware that shading performance's parametrisation may provide alternative insights into the problem. Besides, occupant interaction with the built environment was also set constant, 
essentially limiting the impact of thermal comfort and occupant behaviour on the building's energy performance and vice versa. Third, considering the weather data, the simulated building model's location is defined by the weather station where the weather time series is recorded. The latter ignores aspects such as urban morphology induced wind speed and direction, shading by the surrounding urban context and the effects of the urban heat island [13]. Another limitation of the study concerns the weather data because it considers the IWEC database weather, which has a different timeframe than HadCM3. Therefore the EPW data are expected to slightly overestimate the effect of climate change, as stated by Jentsch et al. [14] and Moazami et al. [72]. However, the weather data are still accurate enough to estimate the projected impact of climate change on building energy use.

\section{Conclusions}

This paper investigates the long-term energy performance of singlefamily detached residential buildings by means of a comprehensive parametric study. Numerous sets of passive design measures were simulated and found effective in achieving high building energy performance. The main findings and conclusions of the conducted analysis are as follows:

- In the analysed single-family residential buildings, the projected warming climate will result in lower heating and higher cooling energy use. However, the total energy use $\left(\mathrm{Q}_{\mathrm{T}}\right)$ is projected to increase in warm climates and decrease in cold climates, while in temperate climates, the evolution of $\mathrm{Q}_{\mathrm{T}}$ depends on the location.

- Low total energy use (i.e. $\mathrm{Q}_{\mathrm{T}} \leq 30 \mathrm{kWh} / \mathrm{m}^{2}$ per year) of single-family residential buildings can be assured to a large extent solely by passive building design measures, particularly in oceanic, warm and temperate climates.

- In all the considered climates, it will be difficult to completely neutralise climate change effect on building energy use for heating and cooling by employing the studied passive building design measures. This issue is especially alarming in warm climates, where total energy use is projected to increase compared to the historical period substantially.

- The most effective passive design measure for long-term climate adaptation of residential buildings is in all the analysed locations applying lower WFR, which in warm climates needs to be supplemented by lower $\alpha_{\text {sol }}$. Due to global warming, the overall importance of low $\mathrm{U}_{\mathrm{O}}$ and $\mathrm{U}_{\mathrm{W}}$ values will decrease to a certain extent, as illustrated by a slight increase in the average $U$ values of building models in the 5th percentile. However, selecting a combination of passive design measures depends largely on whether one aims for a heating or a cooling dominated building, which leads to different seasonal energy demands.

- The energy efficiency of residential buildings may be further improved by active building measures (e.g. heat recovery ventilation, etc.). Nonetheless, it is inevitable that in a warm oceanic climate, such as Porto's, it would be possible to design a nearly zeroenergy building solely by using appropriate passive design.

- Although the results represent crucial information on the effectiveness and eligibility of passive building measures for achieving low energy use and climate change adaptation, additional research in this field is recommended in order to aid policymakers to develop appropriate strategies and guidelines in terms of future energy performance of buildings and their impact on the overall energy supply network.

\section{CRediT authorship contribution statement}

Luka Pajek: Conceptualization, Methodology, Software, Validation, Formal analysis, Investigation, Data curation, Writing - original draft, Visualization. Mitja Košir: Conceptualization, Methodology,
Validation, Investigation, Resources, Writing - review \& editing, Visualization, Supervision.

\section{Declaration of Competing Interest}

The author declare that there is no conflict of interest.

\section{Acknowledgement}

The authors acknowledge the financial support from the Slovenian Research Agency (research core funding No. P2 - 0158). We would like to thank our colleague Jaka Potočnik for his support in the design of figures. Often overlooked, we acknowledge the developers of EnergyPlus and jEPlus for providing the engineering community with freely available extraordinary tools for building simulations.

\section{References}

[1] Olgyay V. Design with climate. New Jersey, USA: Princeton Univ Press; 1963.

[2] Almusaed A. Biophilic and bioclimatic architecture: analytical therapy for the next generation of passive sustainable architecture. London; New York: Springer; 2011.

[3] M. Košir, Climate Adaptability of Buildings: Bioclimatic Design in the Light of Climate Change. Cham: Springer International Publishing; 2019. https://doi.org/ 10.1007/978-3-030-18456-8.

[4] Soutullo S, Sánchez MN, Enríquez R, Olmedo R, Jimenez MJ. Bioclimatic vs conventional building: experimental quantification of the thermal improvements. Energy Procedia 2017;122:823-8. https://doi.org/10.1016/j.egypro.2017.07.413.

[5] Mohammadi A, Saghafi MR, Tahbaz M, Nasrollahi F. The study of climateresponsive solutions in traditional dwellings of Bushehr City in Southern Iran. J Build Eng 2018;16:169-83. https://doi.org/10.1016/j.jobe.2017.12.014.

[6] Szokolay SV. Introduction to architectural science: the basis of sustainable design. Third edition. London ; New York, NY: Routledge; 2014.

[7] Pajek L, Košir M. Implications of present and upcoming changes in bioclimatic potential for energy performance of residential buildings. Build Environ 2018;127: 157-72. https://doi.org/10.1016/j.buildenv.2017.10.040.

[8] Skarbit N, Ács F, Breuer H. The climate of the European region during the 20th and 21st centuries according to Feddema. Int J Climatol 2018;38:2435-48. https://doi. org/10.1002/joc.5346.

[9] IPCC. Intergovernmental Panel on Climate Change 2020. https://www.ipcc.ch/ index.htm (accessed June 29, 2020).

[10] IPCC. Emissions scenarios. A special report of IPCC Working Group III 2000.

[11] IPCC. Intergovernmental Panel on Climate Change AR4 Report 2007.

[12] IPCC. Intergovernmental Panel on Climate Change AR5 Report 2014

[13] Herrera M, Natarajan S, Coley DA, Kershaw T, Ramallo-González AP, Eames M, et al. A review of current and future weather data for building simulation. Build Serv Eng Res Technol 2017. https://doi.org/10.1177/0143624417705937.

[14] Jentsch MF, James PAB, Bourikas L, Bahaj AS. Transforming existing weather data for worldwide locations to enable energy and building performance simulation under future climates. Renew Energy 2013;55:514-24. https://doi.org/10.1016/j. renene.2012.12.049.

[15] Arima Y, Ooka R, Kikumoto H, Yamanaka T. Effect of climate change on building cooling loads in Tokyo in the summers of the 2030s using dynamically downscaled GCM data. Energy Build 2016;114:123-9. https://doi.org/10.1016/j. enbuild.2015.08.019.

[16] Belcher SE, Hacker JN, Powell DS. Constructing design weather data for future climates. Build Serv Eng Res Technol 2016. https://doi.org/10.1191/ 0143624405bt112oa.

[17] Soga K. Development of future weather data using global warming projection: Research on future weather data for designing building and equipment which are adaptable to climate change. Jpn Archit Rev 2018;1:175-90. https://doi.org/ 10.1002/2475-8876.10021.

[18] Jiang A, Liu X, Czarnecki E, Zhang C. Hourly weather data projection due to climate change for impact assessment on building and infrastructure. Sustain Cities Soc 2019;50:101688. https://doi.org/10.1016/j.scs.2019.101688.

[19] Spinoni J, Vogt JV, Barbosa P, Dosio A, McCormick N, Bigano A, et al. Changes of heating and cooling degree-days in Europe from 1981 to 2100. Int J Climatol 2018; 38:e191-208. https://doi.org/10.1002/joc.5362.

[20] Berardi U, Jafarpur P. Assessing the impact of climate change on building heating and cooling energy demand in Canada. Renew Sustain Energy Rev 2020;121: 109681. https://doi.org/10.1016/j.rser.2019.109681.

[21] Bravo Dias J, Soares PMM, Carrilho da Graça G. The shape of days to come: Effects of climate change on low energy buildings. Build Environ 2020;181:107125. https://doi.org/10.1016/j.buildenv.2020.107125.

[22] Bastin J-F, Clark E, Elliott T, Hart S, van den Hoogen J, Hordijk I, et al. Understanding climate change from a global analysis of city analogues. PLoS ONE 2019;14:e0217592. https://doi.org/10.1371/journal.pone.0217592.

[23] Zhou Y, Clarke L, Eom J, Kyle P, Patel P, Kim SH, et al. Modeling the effect of climate change on U.S. state-level buildings energy demands in an integrated assessment framework. Appl Energy 2014;113:1077-88. https://doi.org/10.1016/ j.apenergy.2013.08.034. 
[24] Andrić I, Corre OL, Lacarrière B, Ferrão P, Al-Ghamdi SG. Initial approximation of the implications for architecture due to climate change. Adv Build Energy Res 2019:1-31. https://doi.org/10.1080/17512549.2018.1562980.

[25] Flores-Larsen S, Filippín C, Barea G. Impact of climate change on energy use and bioclimatic design of residential buildings in the 21st century in Argentina. Energy Build 2019;184:216-29. https://doi.org/10.1016/j.enbuild.2018.12.015.

[26] Andrić I, Pina A, Ferrão P, Fournier J, Lacarrière B, Le Corre O. The impact of climate change on building heat demand in different climate types. Energy Build 2017;149:225-34. https://doi.org/10.1016/j.enbuild.2017.05.047.

[27] Zhai ZJ, Helman JM. Implications of climate changes to building energy and design. Sustain Cities Soc 2019;44:511-9. https://doi.org/10.1016/j. scs.2018.10.043.

[28] Kishore N. Impact of climate change on future bioclimatic potential and residential building thermal and energy performance in India. Indoor Built Environ 2021: 1420326X21993919. https://doi.org/10.1177/1420326X21993919.

[29] Pérez-Andreu V, Aparicio-Fernández C, Martínez-Ibernón A, Vivancos J-L. Impact of climate change on heating and cooling energy demand in a residential building in a Mediterranean climate. Energy 2018;165:63-74. https://doi.org/10.1016/j. energy.2018.09.015.

[30] Rodrigues E, Fernandes MS. Overheating risk in Mediterranean residential buildings: Comparison of current and future climate scenarios. Appl Energy 2020; 259:114110. https://doi.org/10.1016/j.apenergy.2019.114110.

[31] Ciancio V, Salata F, Falasca S, Curci G, Golasi I, de Wilde P. Energy demands of buildings in the framework of climate change: An investigation across Europe. Sustain Cities Soc 2020;60:102213. https://doi.org/10.1016/j.scs.2020.102213.

[32] Gercek M, Durmuş Arsan Z. Energy and environmental performance based decision support process for early design stages of residential buildings under climate change. Sustain Cities Soc 2019;48:101580. https://doi.org/10.1016/j. scs.2019.101580.

[33] Harkouss F, Fardoun F, Biwole PH. Passive design optimization of low energy buildings in different climates. Energy 2018;165:591-613. https://doi.org/ 10.1016/j.energy.2018.09.019.

[34] Moazami A, Carlucci S, Nik VM, Geving S. Towards climate robust buildings: An innovative method for designing buildings with robust energy performance under climate change. Energy Build 2019;202:109378. https://doi.org/10.1016/j. enbuild.2019.109378.

[35] Shen P, Braham W, Yi Y, Eaton E. Rapid multi-objective optimization with multiyear future weather condition and decision-making support for building retrofit. Energy 2019;172:892-912. https://doi.org/10.1016/j.energy.2019.01.164.

[36] Shen P, Braham W, Yi Y. The feasibility and importance of considering climate change impacts in building retrofit analysis. Appl Energy 2019;233-234:254-70. https://doi.org/10.1016/j.apenergy.2018.10.041.

[37] Robic F, Micallef D, Borg SP, Ellul B. Implementation and fine-tuning of the Big Bang-Big Crunch optimisation method for use in passive building design. Build Environ 2020;173:106731. https://doi.org/10.1016/j.buildenv.2020.106731.

[38] Chiesa G, Acquaviva A, Grosso M, Bottaccioli L, Floridia M, Pristeri E, et al. Parametric Optimization of Window-to-Wall Ratio for Passive Buildings Adopting A Scripting Methodology to Dynamic-Energy Simulation. Sustainability 2019;11: 3078. https://doi.org/10.3390/su11113078.

[39] Gou S, Nik VM, Scartezzini J-L, Zhao Q, Li Z. Passive design optimization of newlybuilt residential buildings in Shanghai for improving indoor thermal comfort while reducing building energy demand. Energy Build 2018;169:484-506. https://doi. org/10.1016/j.enbuild.2017.09.095.

[40] Ciardiello A, Rosso F, Dell'Olmo J, Ciancio V, Ferrero M, Salata F. Multi-objective approach to the optimization of shape and envelope in building energy design. Appl Energy 2020;280:115984. https://doi.org/10.1016/j.apenergy.2020.115984.

[41] Mohammadi A, Saghafi MR, Tahbaz M, Nasrollahi F. Effects of Vernacular Climatic Strategies (VCS) on Energy Consumption in Common Residential Buildings in Southern Iran: The Case Study of Bushehr City. Sustainability 2017;9:1950. https://doi.org/10.3390/su9111950.

[42] Monge-Barrio A, Sánchez-Ostiz Gutiérrez A. Passive Energy Strategies for Mediterranean Residential Buildings. Cham: Springer International Publishing; 2018. https://doi.org/10.1007/978-3-319-69883-0.

[43] Al-Addous M, Albatayneh A. Knowledge gap with the existing building energy assessment systems. Energy Explor Exploit 2020;38:783-94. https://doi.org/ 10.1177/0144598719888100.

[44] Raimundo AM, Saraiva NB, Oliveira AVM. Thermal insulation cost optimality of opaque constructive solutions of buildings under Portuguese temperate climate. Build Environ 2020;182:107107. https://doi.org/10.1016/j. buildenv.2020.107107.

[45] Andrea V, Tampakis S, Karanikola P, Georgopoulou M. The Citizens' views on adaptation to bioclimatic housing design: case study from Greece. Sustainability 2020;12:4984. https://doi.org/10.3390/su12124984.

[46] Košir M, Gostiša T, Kristl Ž. Influence of architectural building envelope characteristics on energy performance in Central European climatic conditions. J Build Eng 2018;15:278-88. https://doi.org/10.1016/j.jobe.2017.11.023.
[47] European Commission. EU Buildings Datamapper. Energy - Eur Comm 2016. https://ec.europa.eu/energy/eu-buildings-datamapper_en (accessed October 20, 2020).

[48] Haggard KL, Bainbridge DA, Aljilani R, Goswami DY. Passive solar architecture pocket reference book. London: Earthscan; 2009.

[49] European Commission. Housing space per person. Energy - Eur Comm 2011. https://ec.europa.eu/energy/content/housing-space-person_en (accessed October 18, 2020).

[50] Eurostat. Household composition statistics - Statistics Explained 2019. https://ec. europa.eu/eurostat/statistics-explained/index.php/Household_composition_ statistics\#Household_size (accessed October 18, 2020).

[51] EN16798-1:2019. Energy performance of buildings - Ventilation for buildings Part 1: Indoor environmental input parameters for design and assessment of energy performance of buildings addressing indoor air quality, thermal environment, lighting and acoustics - Module M1-6 2019.

[52] Dovjak M, Shukuya M, Krainer A. Connective thinking on building envelope Human body exergy analysis. Int J Heat Mass Transf 2015;90:1015-25. https:// doi.org/10.1016/j.ijheatmasstransfer.2015.07.021.

[53] Hou J, Zhang Y, Sun Y, Wang P, Zhang Q, Kong X, et al. Air Change Rates in Residential Buildings in Tianjin. China. Procedia Eng 2017;205:2254-8. https:// doi.org/10.1016/j.proeng.2017.10.069.

[54] Bekö G, Toftum J, Clausen G. Modeling ventilation rates in bedrooms based on building characteristics and occupant behavior. Build Environ 2011;46:2230-7. https://doi.org/10.1016/j.buildenv.2011.05.002.

[55] Tzempelikos A, Athienitis AK. The impact of shading design and control on building cooling and lighting demand. Sol Energy 2007;81:369-82. https://doi. org/10.1016/j.solener.2006.06.015.

[56] EN 15232-1:2018.. Energy performance of Buildings - Part 1: Impact of Building Automation. Controls and Building Management - Modules M10-4,5,6,7,8,9,10 2018.

[57] Pisello AL. 9 - High-albedo roof coatings for reducing building cooling needs. In: Pacheco-Torgal F, Labrincha JA, Cabeza LF, Granqvist C-G, editors. Eco-Effic. Mater. Mitigating Build. Cool. Needs, Oxford: Woodhead Publishing; 2015, p. 243-68. https://doi.org/10.1016/B978-1-78242-380-5.00009-1.

[58] Bergman TL, Lavine A, DeWitt DP, Incropera FP. Incropera's principles of heat and mass transfer. 8. ed., global edition. Singapore: Wiley; 2017.

[59] EnergyPlus 2020. https://energyplus.net/downloads (accessed October 2, 2020).

[60] jEPlus - An EnergyPlus simulation manager for parametrics 2020. http://www. jeplus.org/ (accessed October 19, 2020).

[61] U.S.. Department of Energy. EnergyPlus ${ }^{\text {TM }}$ Version 9.2.0 Documentation. Engineering Reference 2019.

[62] Pajek L, Tekavec J, Drešček U, Lisec A, Košir M. Bioclimatic potential of European locations: GIS supported study of proposed passive building design strategies. IOP Conf Ser Earth Environ Sci 2019;296:012008. https://doi.org/10.1088/17551315/296/1/012008.

[63] Košir M, Potočnik J, Pajek L. Impact of RCP4.5 climate change scenario on the bioclimatic potential of six selected European locations. Int J Sustain Dev Plan 2018;13:1090-102. https://doi.org/10.2495/SDP-V13-N8-1090-1102.

[64] Weather Data for Simulation | EnergyPlus 2020. https://energyplus.net/weather/ simulation (accessed July 22, 2020).

[65] Köppen-Geiger. World map of the Köppen-Geiger climate classification updated The underlying data (High resolution map and data) 2017. http://koeppen-geiger. vu-wien.ac.at/present.htm (accessed June 12, 2020).

[66] ASHRAE Standard 169-2013. Climatic Data for Building Design Standards 2013.

[67] University of Southampton, Energy and Climate Change Division. CCWorldWeatherGen - Climate Change World Weather File Generator for WorldWide Weather Data 2020. http://www.energy.soton.ac.uk/ccworldweathergen/ (accessed June 29, 2020).

[68] Field C, Barros V, Intergovernmental Panel on Climate Change. Climate Change 2014: impacts, adaptation, and vulnerability: Working Group II contribution to the fifth assessment report of the Intergovernmental Panel on Climate Change 2014.

[69] Attia S, Gobin C. Climate change effects on Belgian households: a case study of a nearly zero energy building. Energies 2020;13:5357. https://doi.org/10.3390/ en13205357.

[70] Summa S, Tarabelli L, Ulpiani G, Di Perna C. Impact of climate change on the energy and comfort performance of nZEB: a case study in Italy. Climate 2020;8: 125. https://doi.org/10.3390/cli8110125.

[71] Pajek L, Košir M. Climate change impact on the potential occurrence of overheating in buildings. Smart Build. City Durab. Sustain., Seoul, S. Korea: Seoul: Institute for sustainable built environment.; 2019, p. 411-4.

[72] Moazami A, Carlucci S, Geving S. Critical Analysis of Software Tools Aimed at Generating Future Weather Files with a view to their use in Building Performance Simulation. Energy Procedia 2017;132:640-5. https://doi.org/10.1016/j. egypro.2017.09.701. 